\title{
Spatial Variability and Radiative Impact of Aerosol along the Brahmaputra River Valley in India: Results from a Campaign
}

\author{
Shyam Sundar Kundu' ${ }^{1,2}$, Arup Borgohain ${ }^{1}$, Nilamoni Barman1, Meenakshi Devi², P. L. N. Raju ${ }^{1}$ \\ ${ }^{1}$ North Eastern Space Applications Centre, Umiam, Shillong, India \\ ${ }^{2}$ Department of Physics, Gauhati University, Guwahati, India \\ Email: *ssk.nesac@gmail.com
}

How to cite this paper: Kundu, S.S., Borgohain, A., Barman, N., Devi, M. and Raju, P.L.N. (2018) Spatial Variability and Radiative Impact of Aerosol along the Brahmaputra River Valley in India: Results from a Campaign. Journal of Environmental Protection, 9, 405-430.

https://doi.org/10.4236/jep.2018.94026

Received: February 21, 2018

Accepted: April 27, 2018

Published: April 30, 2018

Copyright $\odot 2018$ by authors and Scientific Research Publishing Inc. This work is licensed under the Creative Commons Attribution International License (CC BY 4.0).

http://creativecommons.org/licenses/by/4.0/

\begin{abstract}
The first ever land campaign to study the spatial variability of the aerosol characteristics along the Brahmaputra river valley (BRV) in Assam, North-Eastern India, was conducted during 2011. Measurements were made over 13 locations for Aerosol Optical Depth (AOD), scattering coefficient, particulate matter, black carbon (BC) concentration and meteorological parameters. The BRV is divided into three sectors longitudinally viz western sector (WS), central sector (CS), and eastern sector (ES). Significant Spatial heterogeneity in AOD and $\mathrm{BC}$ concentration was observed $(\mathrm{p}<0.05)$ with the highest values over WS and a continual decrease from WS to ES with aerosol dominance in PM2.5 category along the entire valley. The Angstrom coefficient measured using different wavelength pairs showed spatial variability indicating dominance of fine particles over WS and coarse particles in ES with a probable bimodal distribution. The scattering and absorption coefficient shows dominance of both types of aerosol over WS than other areas. The shortwave radiative forcing was higher over the WS than CS and ES of the valley. The campaign revealed that under favorable wind conditions, the BRV is loaded with significant amount of natural and anthropogenic aerosol during local winter and is influenced by the long-range transport of aerosols from the Indo-Gangetic plain.
\end{abstract}

\section{Keywords}

Brahmaputra Valley, Aerosol, Radiative Forcing, Land Campaign, Black Carbon

\section{Introduction}

Aerosols play a key role in climate system by altering the global radiation budg- 
et, directly by scattering and absorbing the incoming radiation or indirectly by changing the cloud microphysical properties [1] [2] [3] [4]. The estimation of aerosol radiative forcing (RF) comes with large uncertainties [4] [5] and aerosols dominate the uncertainty in the total anthropogenic RF [5] [6]. This uncertainty arises primarily due to unavailability of adequate information on spatial and temporal distribution of aerosol across the globe [7] [8]. This uncertainty can be greatly reduced through accurate measurements of optical, physical, and chemical properties of aerosols through continuous measurements from ground-based networks, ships, aircrafts, balloons, and satellites, collecting data through field experiments supported by numerical modeling [9].

The Brahmaputra River Valley (BRV) of Southeast Asia recently has been experiencing regional climate change due to aerosol [10]. Several studies have shown that on a global scale the largest source of $\mathrm{BC}$ aerosols has been the South East Asia [11] [12]. Large scale biomass burning aided by transport of pollution form Indo-Gangetic plain (IGP) is the reason for dominant source of carbonaceous aerosols over this region [13]. The region with all its natural diversities, high population density, diverse living habits, and the growing industrialization and urbanization calls for detail investigation on aerosol properties [14]. Unfortunately, in the BRV region of India, which is home to about 20 million people and several biodiversity hotspots, no systematic measurement of aerosol over space and time has been done. A few studies by Gogoi et al. [15] [16] and Pathak et al. [17] have reported short and long term optical and physical properties of aerosol over Dibrugarh (an urban location in eastern Assam, India) during last few years and related them with the synoptic meteorology and long range transport. Aerosol measurements have also been made over Guwahati city with an indigenously developed LIDAR [18] [19].

During last two decades, several field experiments have been conducted with multi-platform measurements and multi-institutional participation. The most significant experiment among them are Indian Ocean Experiment (INDOEX) [20], Arabian Sea Monsoon Experiment (ARMEX) [21], the Intercontinental Chemical Transport Experiment (INTEX) [22], African Monsoon Multidisciplinary Analysis (AMMA) [23], Integrated Campaign for Aerosols, gases and Radiation Budget (ICARB) [14], Winter phase of ICARB (W-ICARB) [24], Geostationary Earth Radiation Budget Inter-comparisons of Longwave and Shortwave (GERBILS) [25], Arctic Research of the Composition of the Troposphere from Aircraft and Satellites (ARCTAS) [26], the Amazonian Aerosol Characterization Experiment 2008 (AMAZE-08) [27], the Integrated project on Aerosol Cloud Climate and Air Quality interactions (EUCAARI) [28], Atmospheric Brown Clouds East Asian Regional Experiment (ABCEARE) [29], Cloud-Aerosol Interaction and Precipitation Enhancement Experiment (CAIPEEX) [30] etc, which have improved our understanding of regional aerosol properties and their radiative forcing. Also two separate land campaigns, viz., Land campaign-I (LC I) over southern and coastal India [31], Land campaign-II (LC II) over IGP and 
central Indian region [31] have been conducted.

It is evident that field experiments give the unique opportunity of collecting data over an extended spatial domain within a short time span that is useful in bringing out the special features of aerosols within the campaign area. The Brahmaputra valley in north eastern region (NER) of India with a unique terrain is among the highest rainfall receiving zones in world (Cherrapunjee and Mawsynram that receive world's highest annual rainfall are within this region). Majority of the population in NER resides in the Brahmaputra valley spanning from east to west in the state of Assam. The valley is highly vulnerable to aerosols loading during winter (Nov-Feb) and pre-monsoon season (March-May) owing to the fact that the valley has hills of altitude more than $1500 \mathrm{~m}$ all around (Figure 1(a)), except a narrow opening in the west [15]. The wind over the region is primarily westerlies during the winter and pre-monsoon season that has the potential to carry dust laden air from north-west and west Asian countries along with the contribution from IGP [13] [32]. The winter is also mostly dry with daytime relative humidity remaining below $50 \%$ for most of the times. The aerosol within the atmospheric boundary layer therefore has the potential to remain over the area for long duration. The north eastern part of India has not been explored much either in the form of fixed station measurements or during any of the campaigns mentioned above except partly during the CAIPEEX program [30]. Therefore, to examine the spatial variability of the aerosol characteristics along the BRV, a land campaign was conducted by North Eastern Space Applications Centre (NESAC) in collaboration with Dibrugarh University, by collecting in-situ data from west to east along the BRV during the period from February 3 to March 2, 2011. In this paper, we present the results of columnar and surface aerosol measurements, absorption and scattering measurements carried out during the campaign. The RF calculated using SBDART model for the campaign locations are also presented in this paper.

\section{Site Description and Meteorology}

The campaign was conducted along the Brahmaputra River flowing east to west in the Assam state in India. The Brahmaputra Valley is surrounded by the mountains of Yanan to the East, the Meghalaya plateau and Nagaland hills in the South, and the Himalayan Mountains and the Tibetan plateau to the North. The valley has a narrow opening is the west towards the IGP in India making the region vulnerable to aerosol transport and trapping over the BRV (Figure 1(a)). The campaign covered a road distance of about $800 \mathrm{~km}$ extending from $89.97^{\circ} \mathrm{E}$ to $95.55^{\circ} \mathrm{E}$ and $26.1^{\circ} \mathrm{N}$ to $27.6^{\circ} \mathrm{N}$, starting at Dhubri (westernmost point) and ending at Doomdoma (easternmost point) as shown in Figure 1(b). The 13 selected locations where measurements were taken are (sequenced as per their position from west to east along the valley with a abbreviation used for the station, latitude, longitude, and altitude from mean sea level shown within the parenthesis) Dhubri (DHB, $26.1^{\circ} \mathrm{N}, 89.97^{\circ} \mathrm{E}, 34 \mathrm{~m}$ ), Gossaigaon (GSG, $26.45^{\circ} \mathrm{N}, 89.95^{\circ} \mathrm{E}$, 


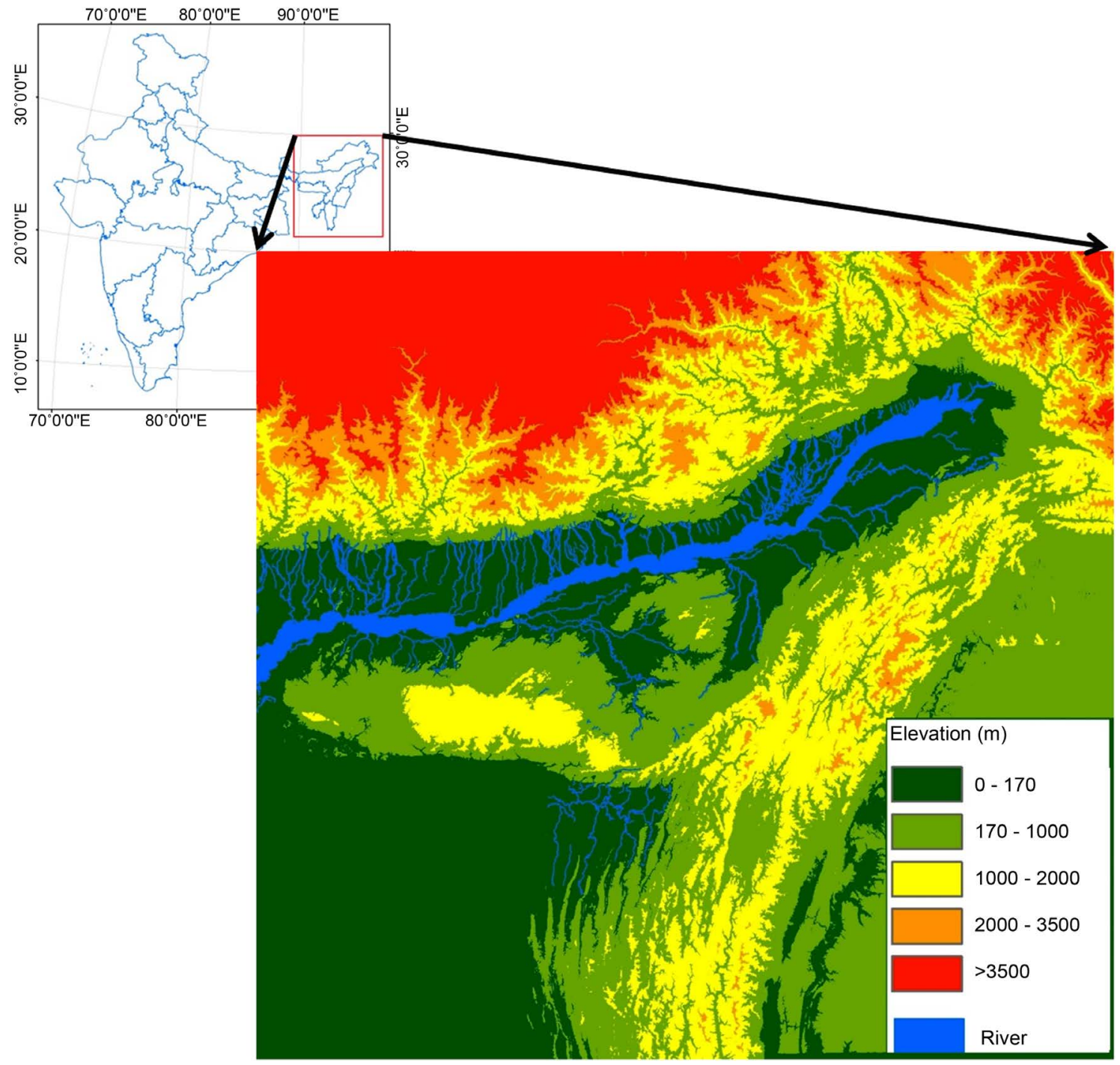

(a)

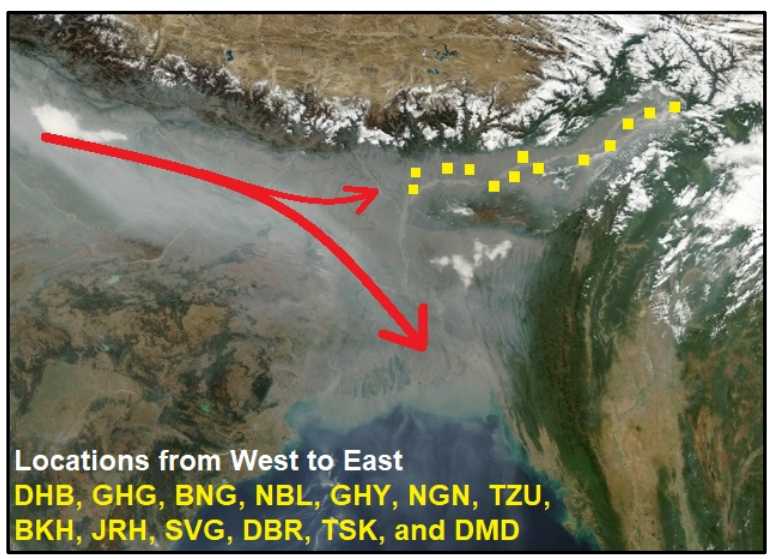

(b)

Figure 1. (a) The rectangular box containing the NER of India with elevation profile. The Brahmaputra River flowing along the flood plains of Assam from east to west; (b) The aerosol river over the Gangetic valley flowing into the Bangladesh and Brahmaputra valley in India as seen in MODIS imagery. The points of data collections are shown as yellow boxes with their names from west to east written over the image. 
$50 \mathrm{~m}$ ), Bongaigaon (BNG, $26.52^{\circ} \mathrm{N}, 90.5^{\circ} \mathrm{E}, 63 \mathrm{~m}$ ), Nalbari (NBL, $26.47^{\circ} \mathrm{N}$, $\left.91.43^{\circ} \mathrm{E}, 42 \mathrm{~m}\right)$, Guwahati (GHY, $\left.26.17^{\circ} \mathrm{N}, 91.75^{\circ} \mathrm{E}, 55 \mathrm{~m}\right)$, Nagaon (NGN, $\left.26.22^{\circ} \mathrm{N}, 92.5^{\circ} \mathrm{E}, 67 \mathrm{~m}\right)$, Tezpur (TZU, $\left.26.7^{\circ} \mathrm{N}, 92.83^{\circ} \mathrm{E}, 48 \mathrm{~m}\right)$, Bokakhat $(\mathrm{BKH}$, $\left.26.63^{\circ} \mathrm{N}, 93.58^{\circ} \mathrm{E}, 76 \mathrm{~m}\right)$, Jorhat $\left(\mathrm{JRH}, 26.73^{\circ} \mathrm{N}, 94.01^{\circ} \mathrm{E}, 116 \mathrm{~m}\right)$, Sivasagar (SVG, $\left.26.95^{\circ} \mathrm{N}, 94.63^{\circ} \mathrm{E}, 95 \mathrm{~m}\right)$, Dibrugarh (DBR $\left.27.3^{\circ} \mathrm{N}, 94.6^{\circ} \mathrm{E}, 108 \mathrm{~m}\right)$, Tinsukia (TSK, $27.5^{\circ} \mathrm{N}, 95.36^{\circ} \mathrm{E}, 116 \mathrm{~m}$ ) and Doomdooma (DMD, $27.6^{\circ} \mathrm{N}, 95.55^{\circ} \mathrm{E}, 114$ $\mathrm{m})$. Most of the sampling locations were so chosen to be away from heavy traffic and any visible pollution sources. Three locations i.e. GHY, JRH, and DBR are urban locations, while GHG, NBL, and DMD are rural locations and the rest are semi-urban locations.

For spatial assessment of aerosols, the valley is grouped into three regions/sectors from west to east, and named as western sector (WS: from DHB to GHY), central sector (CS: from TZU to JRH), and eastern sector (ES: from SVG to $\mathrm{DMD}$ ) based on proximity to the external pollution source and terrain. The major pollution sources in the western sector are two oil refineries and a number of open cast coal mines in close proximity. The region is also characterized by very less forest cover, large open agricultural field and several large sand islands. The CS region is largely covered by moderately dense vegetation and large water bodies, a large number of tea gardens, and one oil refinery. The BRV gets narrowed down in the ES with densely vegetated hills on both side and is mostly covered by tea gardens in addition to several oil fields and coal mines.

The NCEP/NCAR reanalysis data on synoptic wind at $700 \mathrm{mb}$ and $850 \mathrm{mb}$ pressure level over the region is shown in Figure 2. The wind was of the order of $1-3 \mathrm{~m} / \mathrm{s}$ at $850 \mathrm{mb}$ and was mostly north-westerly, while that at $700 \mathrm{mb}$ was

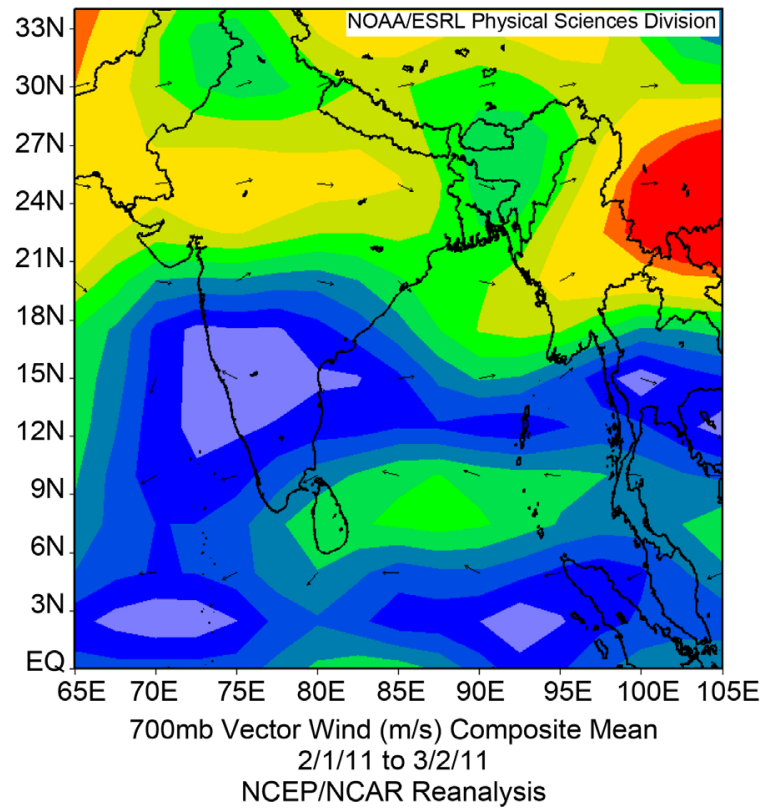

(a)

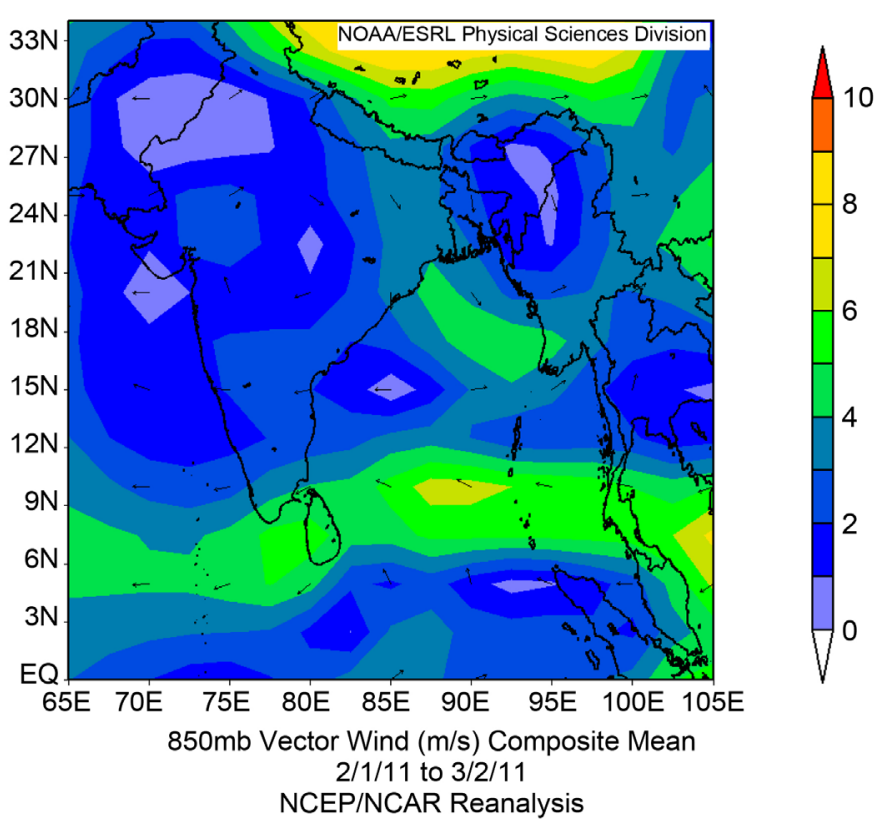

(b)

Figure 2. Synoptic wind pattern over the Indian subcontinent during the campaign period for (a) $700 \mathrm{mb}$ pressure level and (b) $850 \mathrm{mb}$ pressure level. 
relatively strong at $5-6 \mathrm{~m} / \mathrm{s}$ and was westerly over the region. The surface meteorology at the observation sites were obtained from nearby Automatic Weather Stations (AWS, set up and maintained by NESAC). Figure 3 shows spatial variations of the maximum and minimum temperature, mean relative humidity (RH) with one standard deviation as vertical bars on both sides, and maximum wind speed. The maximum and minimum temperature was in the range of $30.3^{\circ} \mathrm{C}-22.6^{\circ} \mathrm{C}$ and $9.7^{\circ} \mathrm{C}-17.5^{\circ} \mathrm{C}$ respectively. The $\mathrm{CS}$ showed more consistent temperature than the other two sectors. The mean $\mathrm{RH}$ remained in the range of $70 \%-80 \%$ with daytime $\mathrm{RH}$ going below $50 \%$ and that reaching to $99 \%$ at night. Short spells of rainfall accumulating to $3-5 \mathrm{~mm}$ was recorded at NGN and TZU during the campaign. The entire campaign period remained dry barring this rainfall episode. Surface wind remained north-westerly and is weak throughout the valley with higher wind speed observed over the WS.

\section{Instruments and Model Description}

The measurements were made continuously for 48 hours in each location using Microtops Sunphotometer, Aethalometer, Integrating Nephelometer, Quarts Crystal Microbalance Impactor, and Automatic Weather Station. A Toyota quails vehicle was internally modified and the equipments were placed inside the vehicle. The air inlet was placed at a height of more than $10 \mathrm{~m}$ from ground. The vehicle had an uninterrupted power supply system with battery backup for up to 3 hours. However, due to frequent load shedding in Assam during the campaign period, data could not be collected for few hours in a few stations. No data could
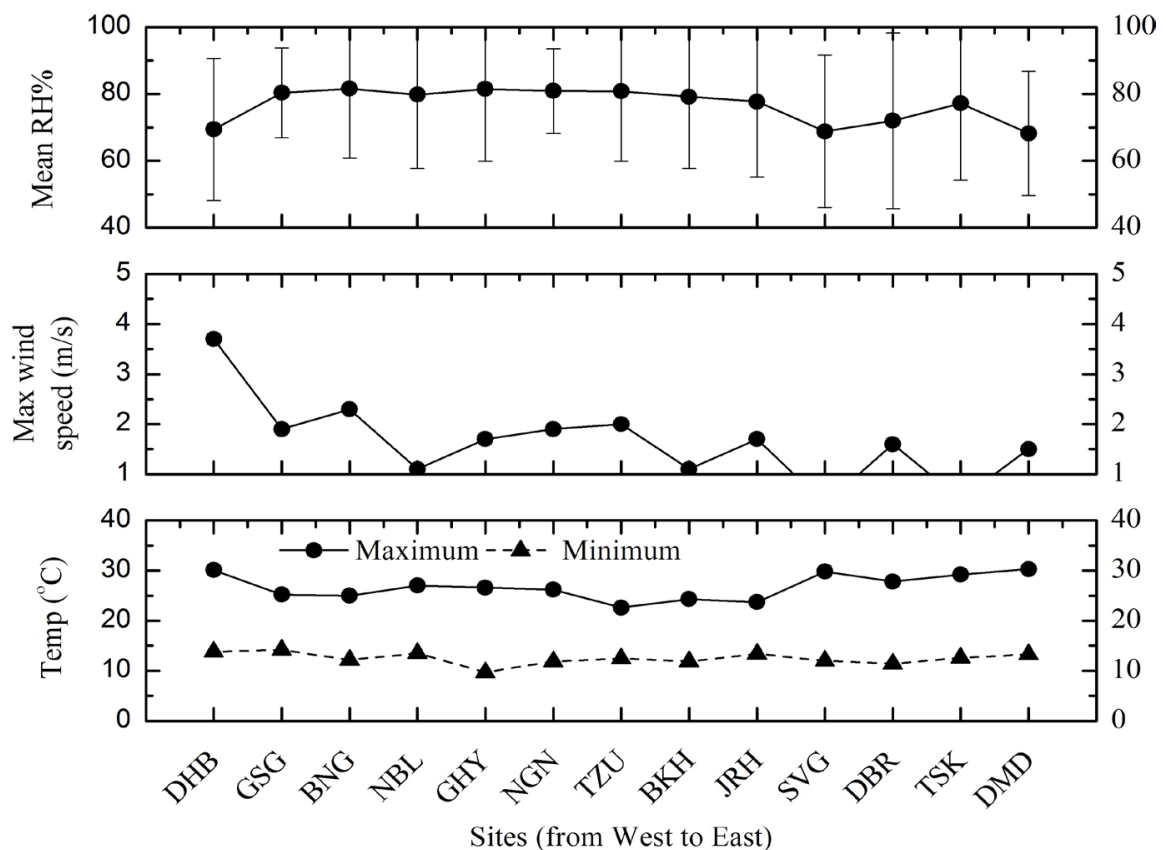

Figure 3. Variation of mean relative humidity (top), max. wind speed (middle) and max. and min. temperature over the measurement locations. The vertical bars represent one standard deviation on both sides. 
be collected using Sunphotometer over NGN due to overcast situation during both the days scheduled for the station. The Sunphotometer and the Nephelometer were 5 months and 3 months old instruments respectively when the campaign was conducted. The factory calibration was therefore valid for both these instruments. The Aethalometer, being 3 years old during the campaign period, was calibrated two months prior to the campaign by the Indian authorized agent of the manufacturer of the instrument. A brief description about the instruments and models used is provided below.

\subsection{Aethalometer}

A portable Aethalometer (Magee Scientific, model AE42) was used for measurement of Black Carbon (BC) concentrations. The instrument measures attenuation of light beam at seven different wavelengths, viz., 370, 470, 520, 590, 660,880 , and $950 \mathrm{~nm}$. The observation at $880 \mathrm{~nm}$ wavelength only was taken for $\mathrm{BC}$ measurement as it is the principal absorber of light at $880 \mathrm{~nm}$. Details of the instrumentation, methodology and uncertainty are discussed elsewhere [33] [34]. The Aethalometer was operated at a flow rate of 4 litres per minute (LPM) and with a temporal resolution of 5 minutes at all the stations. The Aethalometer measurement is subject to uncertainties that arise from the multiple scattering effects in the filter tape and the shadowing effects. The corrections for these uncertainties were done following Weingartner et al. [35] and Nair et al. [34].

\subsection{Quartz Crystal Microbalance Impactor}

A Quartz Crystal Microbalance (QCM) Impactor (model PC-2, California Measurements Inc., USA) was used to measure the aerosol mass concentration at 10 different size ranges (cut-off diameters in $\mu \mathrm{m}$ at $>25,12.5,6.25,3.2,1.6,0.8,0.4$, $0.2,0.1$, and 0.05 for stage 1 to 10 ) assuming a typical density of $2 \mathrm{~g} \cdot \mathrm{cm}^{-3}$ for continental aerosols. The QCM was operated with a flow rate of 240 milliliters per minute. It was operated only when the ambient relative humidity ( $\mathrm{RH}$ ) was less than $75 \%$ as quartz crystals in QCM are sensitive to high RH. The observations were made at sampling accumulation time of $5 \mathrm{~min}$ at every hourly interval during 7:00 hrs to 19:00 hrs (local time) on all days. The error in QCM measurements is less than $15 \%$ [31].

\subsection{Integrating Nephelometer}

The scattering properties of aerosols ( $\beta$ sca) were measured using an Integrating Nephelometer (Model 3563, TSI, USA). The Nephelometer makes simultaneous measurement at red, green, and blue wavelengths for the total scattering and back-scattering. It detects scattering properties by measuring light scattered by the aerosol and subtracting light scattered by the gas, the walls of the instrument and the background noise in the detector. It counts photons using the photomultiplier tubes. The photon counts are converted to counting frequencies and then scattering coefficients using calibration constants. The instrument has 
sensitivity of better than $1.0 \times 10^{-7}$ meter $^{-1}$ for light scattering coefficients.

\subsection{Microtops Sunphotometer}

The aerosol optical depth measurements were made using a MICROTOPS II (make: solar light company, Inc, USA) hand-held multi-band Sunphotometer. The instrument has five accurately aligned optical collimators having full field view of $2.5^{\circ}$. The instrument made simultaneous measurement of Aerosol Optical Depth (AOD) at 380, 440, 500, 936, and $1020 \mathrm{~nm}$ wavelengths. The amount of precipitable water in atmospheric column was determined by measurements at $936 \mathrm{~nm}$ (complete water absorption channel) and $1020 \mathrm{~nm}$ (no water absorption). A detailed description about the instrument functions and its calibration and validation is provided by Morys et al. [36].

\subsection{SBDART Model}

The SBDART (Santa Barbara DISORT Atmospheric Radiative Transfer) multiple scattering model [37] was used to estimate the aerosol RF for all the locations along the valley. The model has been developed by the atmospheric science community and is being used widely for the radiative transfer calculations. The major input parameters for RF estimations are AOD, single scattering albedo, asymmetry factor and surface albedo. Other input parameters in the model include are solar zenith angle, which is calculated by specifying a particular date, time, latitude and longitude, and atmospheric profiles (humidity, temperature, ozone and other gasses). Based on the prevailing weather conditions and measured parameters suitable atmospheric model are used.

\section{Results and Discussions}

The aerosol characterization over RBV has been done by studying different optical and physical properties of aerosol and estimating their effect on the radiative balance of the Earth-Atmosphere system. Continuous measurement was made for 48 hours over 13 locations along the valley. The data collected for the entire period of observation was used to estimate the station wise mean. Standard deviation from mean was also computed each station. The observations made are analyzed below.

\subsection{Aerosol Optical Depth}

The aerosol optical depth (AOD) provides the most comprehensive description of optical properties of aerosol. AOD is defined as the integral of the atmospheric extinction coefficient due to aerosol from the surface to the top of the atmosphere [38]. AOD is a highly wavelength dependent parameter due to their different physical and chemical characteristics and knowledge on the spectral dependence of AOD is important for adequately modeling the effects of aerosols on the radiation budget [39]. The qualitative assessment of spectral dependence of AOD can be made by the Angstrom exponent $\alpha$ [40]. A detail discussion on $\alpha$ 
is provided in Section 4.2.

The variation in AOD for all the stations at five representative wavelengths, namely, 380, 440, 500, 936, and $1020 \mathrm{~nm}$ are shown in Figure 4. Vertical lines on top of each bar represent $\pm 1 \sigma$ variation about the mean value. The locations in WS show higher AOD than the locations in CS and ES. One station in ES, namely, TSK shows higher AOD comparable with that in WS locations. No AOD measurement could be done over NGN due to overcast situation there. The variation of AOD along the western to eastern corridor of BRV is consistent at all wavelengths. However, AOD shows more consistency at longer wavelengths (936 and $1020 \mathrm{~nm})$ than at smaller wavelengths $(380 \mathrm{~nm})$. The highest value of AOD at $550 \mathrm{~nm}$ of $1.03 \pm 0.1$ was observed over NBL in WS while lowest value of $0.41 \pm 0.12$ was observed at SVG in ES. The locations in CS show very consistent AOD values in all channels. The regional inhomogeneity observed could be attributed to several reasons, firstly, the locations in WS are closer to the relatively high aerosol dominated IGP and the westerly wind travelling from the IGP (Figure 1(b), Figure 2(a), and Figure 2(b)) could transport a significant amount of aerosol towards the WS locations, which could further propagate towards the locations in CS and ES, but with lesser concentration. Secondly, the WS and CS of the BRV are more densely populated than the ES, leaving reasons for higher anthropogenic aerosol generation over WS. The WS has more agricultural field along the valley than other two sectors, causing more loading of dust aerosol as well over the WS locations. All these contribute to higher concentration of both anthropogenic and natural aerosols over the

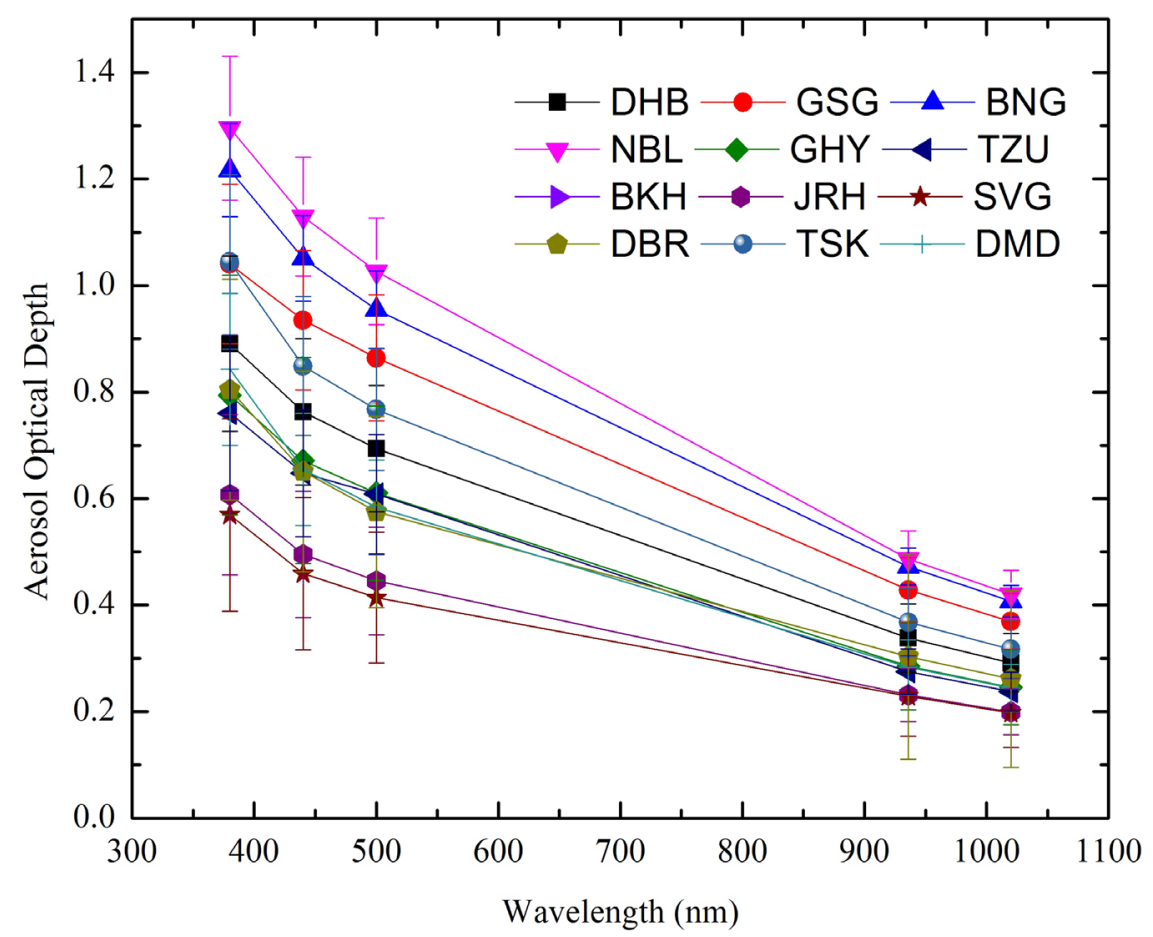

Figure 4. Spectral variation of AOD for all locations along the BRV. The vertical bars represent standard deviation about the mean on both sides. 
locations in WS than CS and ES. Similar observations have been reported by Pathak et al. [41]. AOD values at higher wavelengths are more affected by naturally produced coarser aerosols, while the submicron sized aerosols produced mostly because of various anthropogenic activities contribute maximum to AODs at smaller wavelengths [42]. The higher AOD in all channels over the entire valley suggest both higher natural and anthropogenic aerosol along the valley.

Total aerosol loading in the atmosphere over any location depends on the differences between production of aerosols from all possible sources (either locally produced or transported to that location by wind) and their sinks (either gravitational settling or transported to other locations by wind) [42]. This means that even if there is no difference in source strength of aerosols, any weakening of the sink mechanisms can result in pile up of aerosols in the atmosphere which may manifest itself in terms of higher aerosol optical depth. There was a rainfall of the order of $2-5 \mathrm{~mm}$ over large part of CS and ES, when the vehicle was stationed in NGN. Such a small amount of rainfall cannot do any large scale removal of aerosol from atmosphere. However, still it could cause moderate reduction in AOD over subsequent stations like TZU and BKH. The AOD over JRH and SVG showed lowest value even though data were collected five to seven days after the rainfall event.

\section{2. Ångström Exponent}

Another important parameter used for optical and physical characterization of aerosol is Ångström Exponent (AE, $\alpha$ ), which is computed from the Ångström's [40] empirical formula:

$$
\mathrm{AOD}_{\lambda}=\beta \lambda^{-\alpha}
$$

where $\mathrm{AOD}_{\lambda}$ is the AOD at wavelength $\lambda$ and $\beta$ is the turbidity coefficient and is equal to AOD for $\lambda=1 \mu \mathrm{m}$. Logarithm of Equation (1) provides equation of a straight line between $\ln \mathrm{AOD}_{\lambda}$ and $\ln \lambda$ as:

$$
\ln \mathrm{AOD}_{\lambda}=\alpha \ln \lambda+\ln \beta
$$

Taking ratio of Equation (2), the $\mathrm{AE}$ can be calculated from the spectral values of AOD as:

$$
\alpha=-\left(\mathrm{d} \ln \mathrm{AOD}_{\lambda}\right) /(\mathrm{d} \ln \lambda)
$$

$\mathrm{AE}$ is useful to compare and characterize the wavelength dependence of AOD and columnar aerosol size distribution [39] [43]. A relative increase in the number of fine particles with respect to the coarse mode particles will result an increase in the value of $\mathrm{AE}$ and vice versa. However, $\mathrm{AE}$ estimated using Sun-photometer measured AOD depends on the wavelength pair used for the computation [39] [44] [45]. Reid et al. [45] have shown that AE computed using longer wavelength pair is more sensitive to changes in the amount of coarse mode aerosols while AE computed using shorter wavelength pairs is more sensi- 
tive to changes in the number of nucleation and accumulation mode sized particles. To find the dominating factor which causes $\alpha$ to change from one station to another along the BRV, we have computed this parameter for different wavelength intervals. Figure 5 shows the location wise variation of $\alpha$ computed for three different wavelength intervals $\left(\alpha: 380-936 \mathrm{~nm}, \alpha_{S}: 380-440 \mathrm{~nm}\right.$, and $\alpha_{L}$ : $500-936 \mathrm{~nm}$ ). The AOD at $1020 \mathrm{~nm}$ were not included for computation of AE values because of possible water vapor absorption effects at that wavelength.

We find that $\alpha$ values (computed using entire spectrum) is almost consistent over all locations with highest value of 1.21 over DMD (extreme eastern location) and lowest of 0.98 over GSG, that do not provide any clear picture on relative dominance of either fine mode or coarse mode aerosols along the entire valley. However, the $\alpha_{S}$ values have very significant variation along the valley with lower values over locations in WS (close to 1 ) and higher values in ES (max. of 1.72 for DMD). As AE represent relative abundance in aerosol fine mode fraction and $\alpha_{S}$ is more sensitive to changes in nucleation and accumulation mode aerosol particles, the increase in its value may signify increase in fine mode fraction over the locations from BKH to DMD in CS and ES. However, the $\alpha_{L}$, computed using larger wavelength pairs, decreased as we move from west to east along the BRV, suggesting relative increase in coarse mode fraction as well over the ES. The locations in WS and part of CS covering from DHB to TZU, however, show consistent values of $\alpha$ (close to 1 ) for all wavelength pairs, that do not provide any clarity on the relative dominance of aerosol mode over this region. This calls for a detail investigation on the spectral properties of $\mathrm{AE}$ along the valley, particularly over the ES of the BRV.

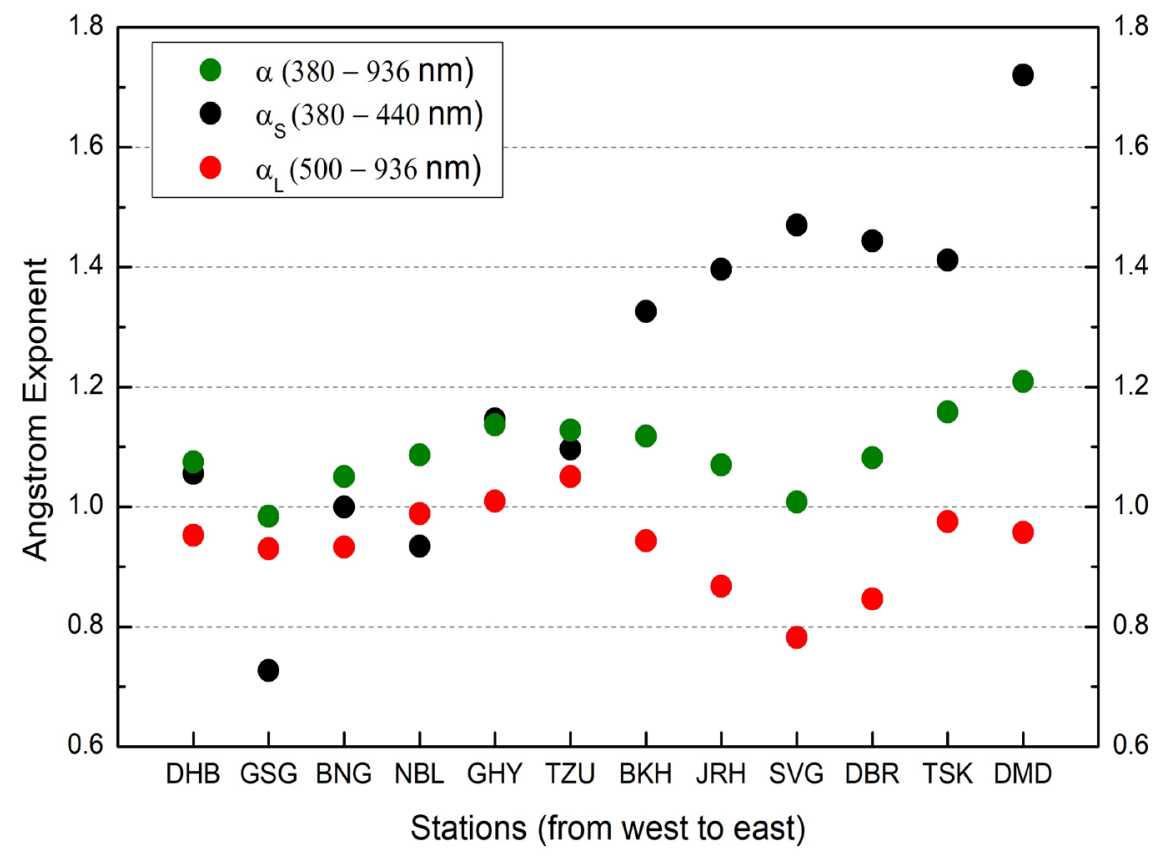

Figure 5. Variation of Angstrom exponent along the campaign trail. The exponent is computed for three different wavelength ranges. 
Since $\mathrm{AE}$ is also observed to vary with wavelength, a more precise empirical relationship between aerosol extinction and wavelength was suggested using a second order polynomial fit [39] [45] [46] [47] [48] [49] given by:

$$
\ln \mathrm{AOD}_{\lambda}=\alpha_{0}+\alpha_{1} \ln \lambda+\alpha_{2}(\ln \lambda)^{2}
$$

where $\alpha_{0}, \alpha_{1}$, and $\alpha_{2}$ are constants. The coefficient $\alpha_{2}$ accounts for a curvature often observed in sun-photometry measurements [50]. As a parameter to quantify the curvature of $\mathrm{AOD}_{\lambda}$, the second derivative of $\ln \mathrm{AOD}_{\lambda}$ versus $\ln \lambda$ is utilized as it is related to the derivative of $\mathrm{AE}$ with respect to $\ln \lambda$ [39] [45] [49]. The second derivative $(\alpha)$ of $\mathrm{AE}$ is a measure of the rate of change of slope with respect to wavelength. From Equations (2) and (4), the following relationship can be obtained:

$$
\alpha^{\prime}=\mathrm{d} \alpha / \mathrm{d} \ln \lambda=-\mathrm{d}\left(\left(\ln \mathrm{AOD}_{\lambda}\right) / \mathrm{d} \ln \lambda\right) / \mathrm{d} \ln \lambda=-2 \alpha_{2}
$$

A curvature in $\ln \mathrm{AOD}_{\lambda}$ versus $\ln \lambda$ plot can provide useful information for type of aerosol [45] [49]. While a concave curve depicts dominance of biomass burning and/or urban/industrial aerosol, a convex curve depicts a dust dominated aerosol [39]. They [39] [45] [49] also concluded that aerosol dominated by coarse modes and having bimodal distribution could have very small curvature for $\ln \mathrm{AOD}_{\lambda}$ versus $\ln \lambda$, making polynomial fit to be linear. Figure 6 shows the plot for $\ln \mathrm{AOD}_{\lambda}$ versus $\ln \lambda$ for all the stations along the BRV. It is clear that none of the station in BRV has any significant curvature for $\ln \mathrm{AOD}_{\lambda}$ versus $\ln \lambda$, suggesting a possible presence of bimodal distribution with presence of both biomass burning aerosols and dust aerosols.

The second derivative of $\mathrm{AE}\left(\alpha^{\prime}=-2 \alpha_{2}\right)$ has been used for qualitative assessment of aerosol particle size. A positive value of $\alpha^{\prime}$ indicates aerosol size distribution

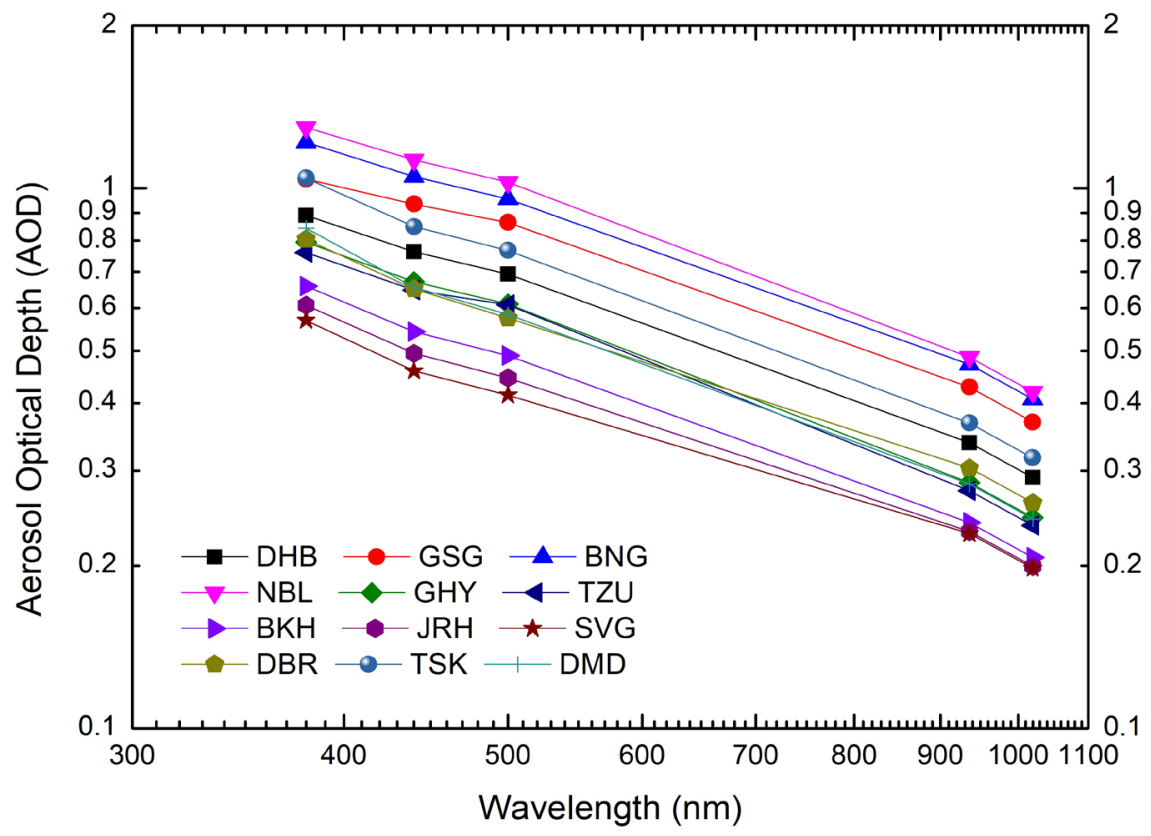

Figure 6. Spectral AOD over the BRV in log scale. 
dominated by fine mode and negative values indicates the same dominated by coarse mode [39] [44] [51]. Kaskaoutis et al. [50] also concluded that the if the values of $\alpha$ computed using shorter wavelength pair is larger than that computed using longer wavelength pair and the second derivative of $\mathrm{AE}$ is negative, that strongly characterizes aerosol size distribution significantly dominated by coarse mode aerosols. The opposite of the above was characteristic of fine mode dominance. Figure 7 depicts the distribution of second derivative of AE along with the AOD at $500 \mathrm{~nm}$ and difference of $\alpha_{S}$ and $\alpha_{L}$ for all the sites along the BRV. The locations in the ES show negative values for second derivative of AE for all locations except over TSK supported with higher value of $\alpha_{S}$ than $\alpha_{L}$. This clearly indicates dominance of aerosol with coarser mode over these locations. TSK, being a railway hub in the ES and has relatively higher population density than other locations in ES, could have more anthropogenic aerosols leading to fine mode fraction dominance. The same can also be inferred from relatively higher AOD over TSK than other locations in ES.

The locations in WS and CS except JRH have negligible difference between the values in $\alpha_{\mathrm{S}}$ and $\alpha_{\mathrm{L}}$, and have moderately higher positive value for the second derivative of AE. This indicates the presence of aerosol distribution with significant presence of both fine and coarse mode aerosols over these locations with a higher number concentration of fine mode aerosols. The AOD at $500 \mathrm{~nm}$ wavelength also is significantly higher over these locations, which also support the presence of aerosols with bimodal distribution over these locations.

\subsection{Aerosol Mass Concentration and Absorption Properties}

The aerosol mass concentrations over all locations along the BRV were measured

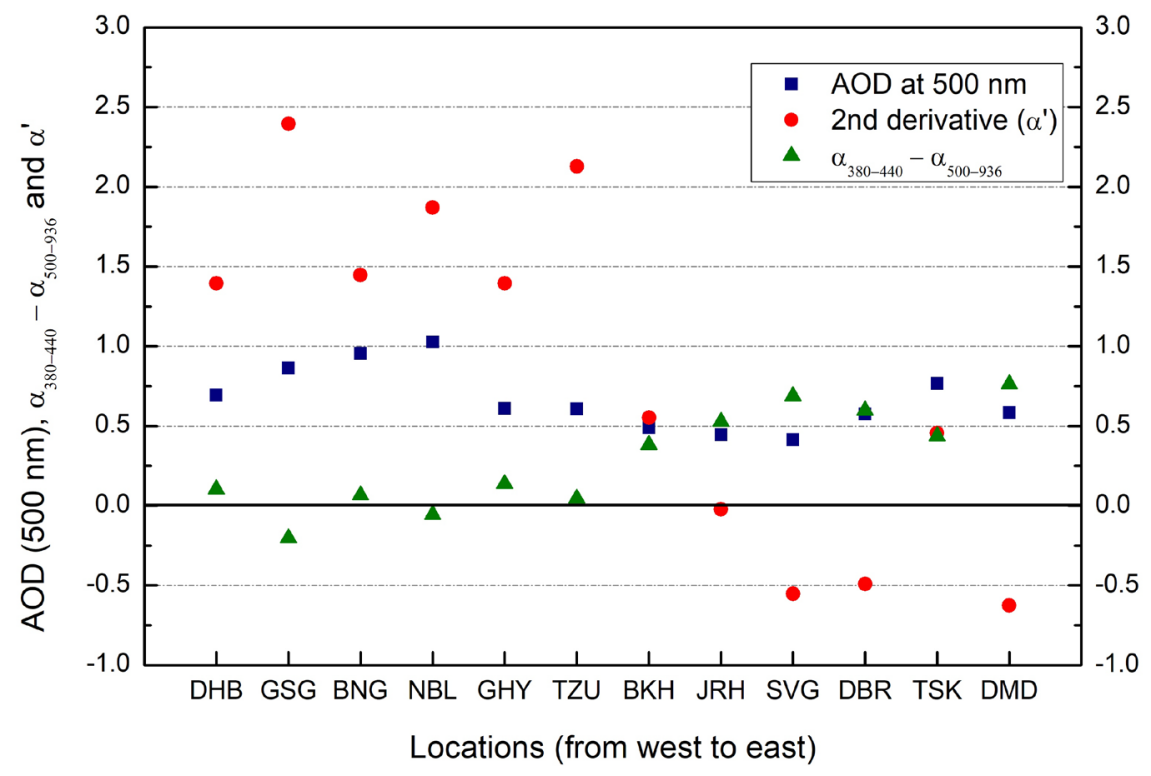

Figure 7. The AOD at $500 \mathrm{~nm}$ wavelength, second derivative of $\mathrm{AE}$, and difference of $\mathrm{AE}$ computed using shorter and longer wavelength pair for all sites along the BRV. The zero value level is shown with a solid black line. 
using the QCM for particulate matter (PM) concentrations, viz., PM10 and PM2.5. The BC mass concentration, which is normally a subset of PM2.5 were also measured using an Aethalometer. Figure 8 shows the variation of these parameters along the valley. The $\mathrm{PM}$ and $\mathrm{BC}$ concentration and its variation along the BRV has been discussed by Pathak et al. [52], using the data collected during the same campaign discussed here. The highest PM concentrations (PM10 and PM2.5) were observed at NBL in WS $\left(53.75 \pm 4.75\right.$ and $\left.51.82 \pm 3.1 \mu \mathrm{g} \cdot \mathrm{m}^{-3}\right)$ with almost similar values at BKH, JRH, and SVG in CS and ES. However at sector level, CS shows the maximum sector average values of $37.73 \pm 10.26$ and $35.12 \pm$ $10.2 \mu \mathrm{g} \cdot \mathrm{m}^{-3}$ respectively for PM10 and PM2.5. Despite the light rain at two sites, NGN and TZU in CS recorded appreciable PM concentrations $(29.82 \pm 3.7$ and $28.1 \pm 2.1 \mu \mathrm{g} \cdot \mathrm{m}^{-3}$ for PM10). This concentration could be attributed to contribution from local sources. Most of the sites in ES show low PM concentrations which lead to a sector based average value of $27.68 \pm 9.74$ and $25.08 \pm 9.95 \mu \mathrm{g} \cdot \mathrm{m}^{-3}$, respectively for PM10 and PM2.5. The regional inhomogeneity observed for the $\mathrm{PM}$ and $\mathrm{BC}$ concentration also has similar causes as those discussed in Section 4.1.

Two locations in WS named DHB and GHG showed significantly lower value of $\mathrm{PM}$, irrespective of relatively higher value of $\mathrm{BC}$ concentration and $\mathrm{AOD}$. The AOD is a columnar data with contribution from aerosol in the entire column over the measurement sites unlike the $\mathrm{BC}$ and $\mathrm{PM}$ concentrations representing the surface level aerosol. There could be significant amount of aerosol well above the surface over these two locations contributing to the overall increase in AOD. This observation also supports the concept of significant contribution of

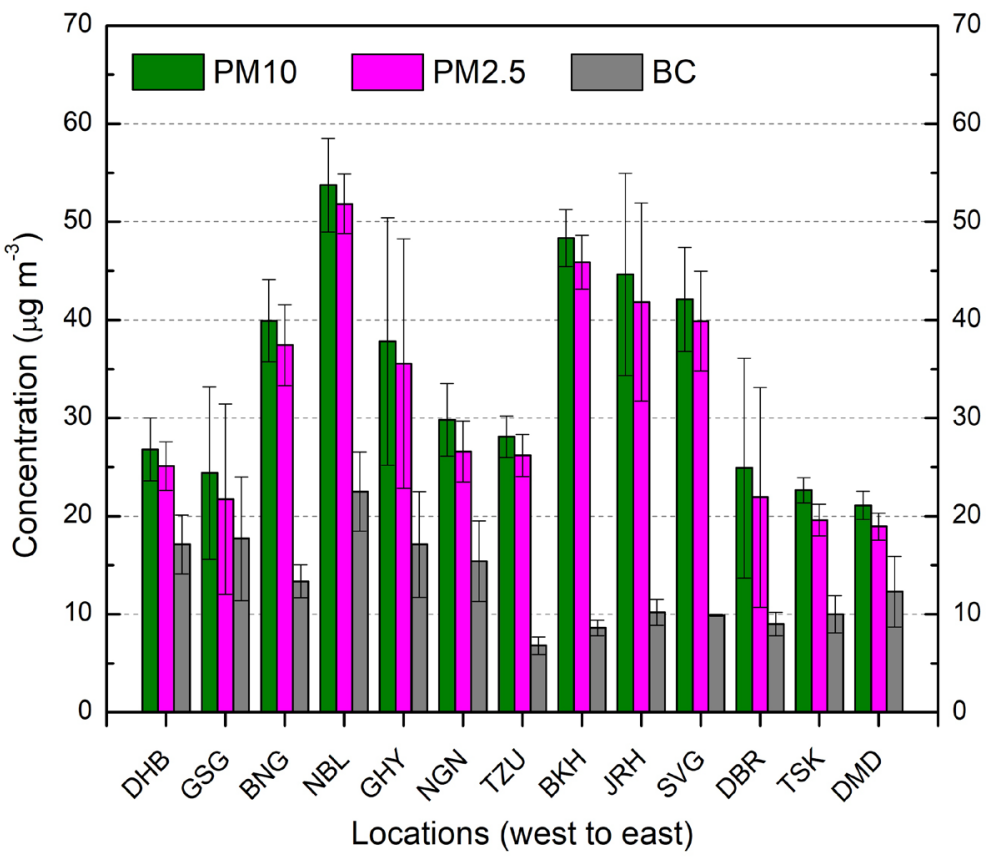

Figure 8. Variation of BC, PM10, and PM2.5 along the campaign train with vertical bars representing one standard deviation on both sides. 
transported aerosol from the locations west of the BRV, primarily the IGP, affecting the locations in the WS more than CS and ES. In addition, a relatively higher wind speed over DHB could uplift more aerosols at a higher altitude, while almost calm weather over other locations confines aerosol at a lower surface level.

The daily mean $\mathrm{BC}$ mass concentration varies between highest value of $22.52 \pm$ $4.05 \mu \mathrm{g} \cdot \mathrm{m}^{-3}$ at NBL and lowest value of $6.82 \pm 0.09 \mu \mathrm{g} \cdot \mathrm{m}^{-3}$ at TZU. The WS locations again are rich in $\mathrm{BC}$ concentration near the surface $\left(17.55 \pm 3.26 \mu \mathrm{g} \cdot \mathrm{m}^{-3}\right)$ as compared to the other two sectors having almost similar mean concentration of $\sim 10.3 \mu \mathrm{g} \cdot \mathrm{m}^{-3}$. Pathak et al. [52] also reported an appreciable day-to-day variability in $\mathrm{BC}$ concentration particularly at the western locations and at DMD in the eastern sector. This was attributed partly to the proximity of these locations to coal mines or coal dumps over extreme eastern locations. A decreasing trend in $\mathrm{BC}$ concentration was observed from west to east which could be attributed to similar reasons discussed in Section 4.1.

The aerosol absorption coefficient $\left(\beta_{\text {abs }}\right)$ was computed for $520 \mathrm{~nm}$ wavelength and is shown in Figure 9. $\beta_{\text {abs }}$ was computed by measuring the attenuation (ATN) of the incident light transmitted through the sample spot on a quartz fiber filter loaded in the Aethalometer. The absorption exponent was computed using the raw absorbance data recorded by Aethalometer. The absorption coefficient provides an idea about the amount of particulate absorption in the atmosphere and it is one of the critical parameter for radiative forcing calculations [53]. Absorption coefficient at $520 \mathrm{~nm}$ shows similar spatial variability along the $\mathrm{BRV}$ as that of the $\mathrm{BC}$ mass concentration indicating one to one relationship

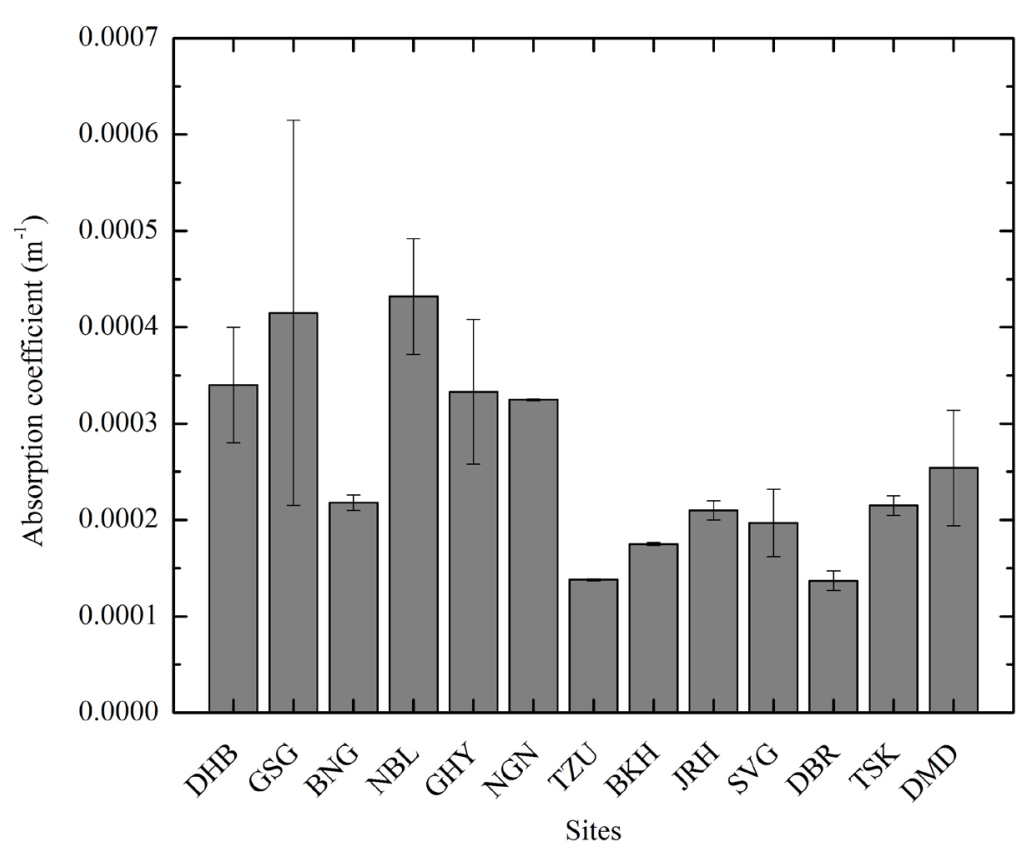

Figure 9. Aerosol absorption coefficient along the campaign trail in BRV. The vertical bars represent one standard deviation on both sides. 
between the mass concentration and their absorbing properties. It has been seen in some of the earlier studies that aerosols emitted because of biomass/biofuel burning exhibit stronger absorption characteristics than those produced because of fossil fuel burning [54] [55]. The relative dominance of absorbing aerosol is evident over the locations in ES and CS than over the WS. The properties of aerosol absorption coefficient and absorption Angstrom exponent over the campaign sites has been discussed by Pathak et al. [52].

\subsection{Aerosol Scattering Properties}

The aerosol scattering coefficient $\left(\beta_{\text {sca }}\right)$ was computed using the Integrating $\mathrm{Ne}$ phelometer data at $530 \mathrm{~nm}$. Figure 10 shows the variation of aerosol scattering coefficient at $530 \mathrm{~nm}$ along the valley. The vertical lines on top of each bar represent $\pm 1 \sigma$ variation about the mean. The water-soluble inorganic species like sulfates, nitrates, etc. make very significant contribution to the scattering coefficient [2]. These could arise from emissions associated mainly with combustion of fossil fuel, fertilizers, and some organic aerosols arising from biomass combustion [2]. The scattering coefficients over the WS locations are almost $7-8$ times higher than that over ES and a few locations in CS. The highest value of $0.00183 \pm 0.0009$ is observed over BNG and lowest value of $0.00022 \pm 0.0006$ is observed over TZU. During the winter seasons, we see a lot of waste burning activities, such as burning agricultural fields, small scale forest fires, shrubs etc. in various parts of the valley and all these contribute significantly to the production of both scattering and absorbing type species in the atmosphere. Moreover during this season, aerosols which are either locally produced or transported from

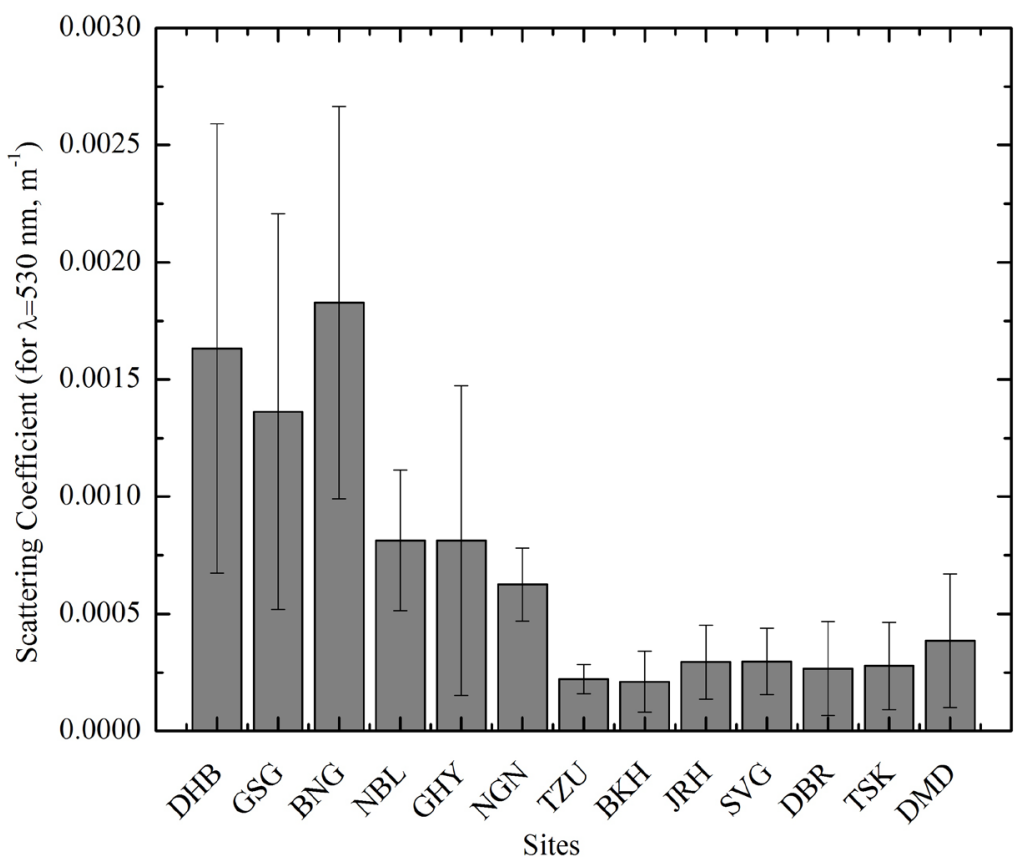

Figure 10. Variation of aerosol scattering coefficient along the BRV. The vertical bars represent one standard deviation on both sides. 
other regions are constrained within a shallow boundary layer having smaller ventilation coefficient and this causes their concentration to rise near the surface level [56]. The locations in the WS, being closer to the IGP and also large amount of biomass burning in this region causes higher scattering coefficient over the locations. Dust is another key parameter that gives higher scattering coefficient. The presence of large scale agricultural field and moderate level wind speed also adds to the overall scattering aerosol loading over the locations in WS and over some locations in CS. The similar trend observed for the absorption coefficient and scattering coefficient along the BRV, suggest same source of aerosol contributing to absorption and scattering.

The Atmosphere contains simultaneous presence of both scattering and absorbing type aerosols with contrasting effect in aerosol radiative forcing [42]. The single scattering albedo (SSA, $\omega_{0}$ ) which is the ratio of scattering to extinction coefficient of aerosols, provide important information on relative potential of the aerosol in cooling or warming of the atmosphere. The knowledge of single scattering albedo is very crucial as small error in its magnitude can produce large difference in the estimated values of aerosol radiative forcing [57]. The magnitude of $\omega_{0}$ considered as an index for the relative dominance of scattering with respect to absorbing type of aerosols, which can range from 0 (purely absorbing) to 1 (purely scattering). Ganguly et al. [55] have shown that for the same aerosol optical depth (AOD) and mass loading over Bay of Bengal, atmospheric forcing by aerosols is very sensitive to $\omega_{0}$. Over land areas, knowledge of $\omega_{0}$ becomes even more critical and any small change in its value can have larger impact resulting from flux changes within and below the aerosol layer such as differential heating rates, changes in atmospheric stability and cloud formation [58]. In this particular study, we have estimated the single scattering albedo of aerosols from the ratio of scattering coefficient at $0.53 \mu \mathrm{m}$ using Nephelometer and its sum with the absorption coefficient at $0.52 \mu \mathrm{m}$ measured using Aethalometer. Measured values of scattering coefficient are associated with some angular truncation loss which is an inherent and unavoidable problem for all Nephelometers [59]. Taking into account all possible sources of error, overall uncertainty in the estimated value of $\omega_{0}$ during the present study is around $8 \%$. Figure 11 shows the variation of $\omega_{0}$ along the BRV with vertical lines on top of each bar representing $\pm 1 \sigma$ variation about the mean.

The lowest value of $\omega_{0}$ was found to be at BKH in CS having value of $0.55 \pm$ 0.07 and highest value of $0.89 \pm 0.05$ was observed at BNG in WS. The SSA values over all stations except DHB and BNG is very high (below 0.8) indicating relative dominance of absorbing aerosols along the entire BRV. Pathak et al. [41] has also reported higher absorbing aerosol over Dibrugarh (DBG in ES) that is comparable to many locations in IGP. Tripathi et al. [60] reported SSA value for Delhi and Kanpur to be 0.67 and 0.76 during pre-monsoon period and December month respectively. The SSA values over the BRV are also comparable to that over IGP regions. The SSA also shows similar trend with respect to the 


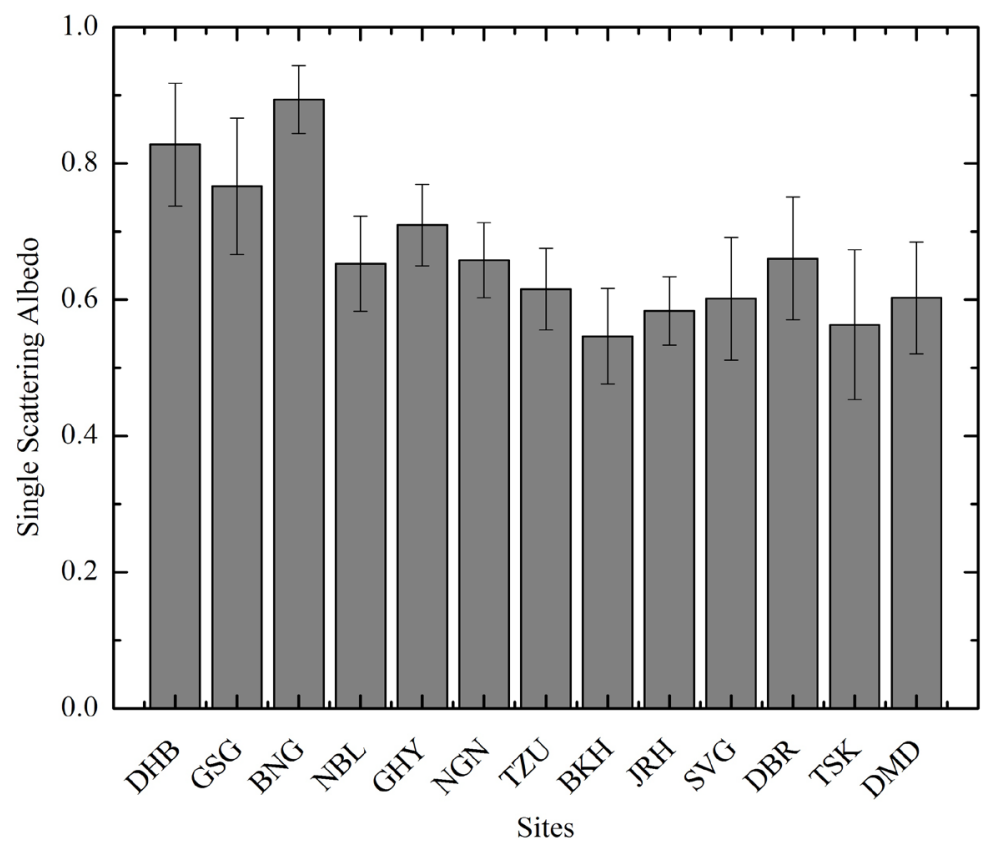

Figure 11. Mean value of single scattering albedo over the measurement locations. The vertical bars represent one standard deviation on both sides.

trend depicted by the scattering coefficient and absorption coefficient along the $\mathrm{BRV}$. The net aerosol loading over the WS is of course significantly high along with high SSA, high $\beta_{\text {abs }}$ and $\beta_{\text {sca }}$ than that over the ES and CS

\subsection{Aerosol Radiative Forcing}

The radiative effect due to aerosol-radiation interactions also known as direct radiative forcing (RF) is the change in radiative flux caused by the combined scattering and absorption of radiation by anthropogenic and natural aerosols. The RF requires knowledge of the spectrally varying aerosol extinction coefficient, single scattering albedo, and phase function, which can in principle be estimated from the aerosol size distribution, shape, chemical composition and mixing. Short wave aerosol radiative forcing ranging from $0.25-4.0 \mu \mathrm{m}$ is calculated using the Santa Barbara DISORT Atmospheric Radiative Transfer (SBDART) model [37]. The forcing was calculated for all the stations separately where data were collected during the campaign. The optical properties (that are not available, but required for RF calculation like phase function, asymmetry parameter, etc.) obtained from Optical properties of Aerosol and Cloud (OPAC) [61] model outputs and were used as input for the SBDART model. The model generated AODs at five wavelengths (at $380 \mathrm{~nm}, 440 \mathrm{~nm}, 500 \mathrm{~nm}, 936 \mathrm{~nm}$ and $1020 \mathrm{~nm}$ ) were validated with the measured AOD obtained using Microtops Sunphotometer, and those outputs of OPAC for which root mean square error is minimum between observed and measured values were used for computation of radiative forcing

Spectral dependence of surface albedo for the entire short wave range was 
taken care by using combination of different surface types for each site. With this methodology, radiative forcing estimates were made for Top of the Atmosphere (TOA, $100 \mathrm{~km}$ for the present case), Atmosphere (ATM), and Surface (SUR)

Figure 12 shows TOA, ATM, and SUR level radiative forcing for all the locations along the campaign trail. High atmospheric forcing of the order of 54 $\mathrm{Wm}^{-2}$ was observed over GSG and NBL in the WS and the lowest radiative forcing of $29.91 \mathrm{Wm}^{-2}$ was found over SVG in ES. The RF at ATM level is positive for all locations with a gradual decrease in RF as we move from west to east along the BRV. The pattern is similar to that observed by AOD and BC concentration along the $\mathrm{BRV}$. The radiative forcing was found to be reducing at the rate of $3.08 \mathrm{Wm}^{-2}$ per degree longitude along the Brahmaputra valley as we move from west to east.

The positive forcing arises due to the absorption of radiation by significantly larger concentration of black carbon in the atmosphere over all sites. The TOA RF also is positive for all locations except the GHY and JRH, which are the two major urban locations along the BRV. Significant contribution of absorbing aerosols to lower atmospheric warming over different parts of NE region of India has also been reported by Gogoi et al. [62]. Pathak et al. [63] have reported that atmospheric forcing due to composite aerosols over Imphal (a valley location south of DMD in NE region of India) was $25.1 \mathrm{Wm}^{-2}$ at, over Shillong (another hilly station south of GHY) was $31.6 \mathrm{Wm}^{-2}$ and over Agartala (an urban station in Tripura state) was $56.2 \mathrm{Wm}^{-2}$. The global mean clear-sky ARF at the TOA and the surface are however found to be negative [64].

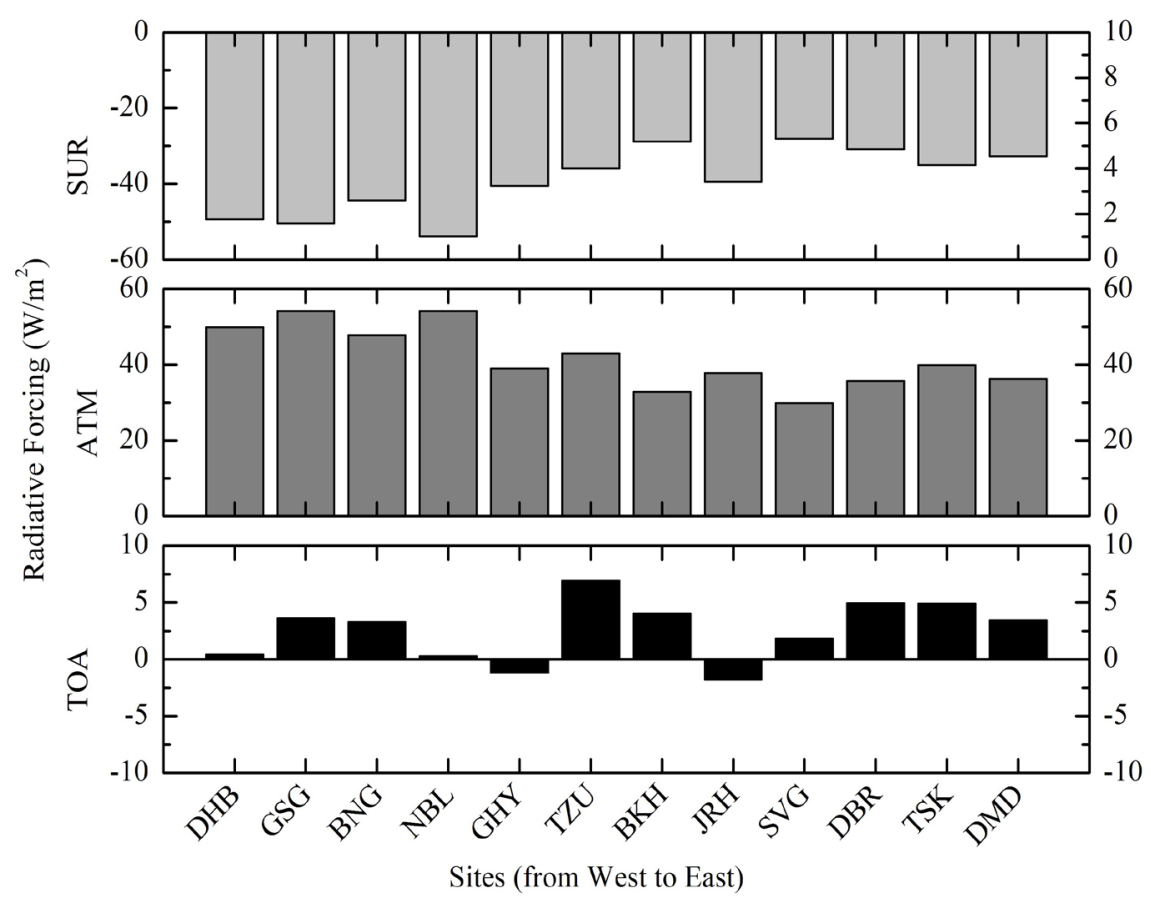

Figure 12. Shortwave radiative forcing over all the campaign locations. 


\section{Summary and Conclusions}

The first ever land campaign along the BRV was conducted during February 3 to March 2, 2011 along the western to eastern corridor of the Brahmaputra River valley in Assam. The campaign revealed significant regional heterogeneity in aerosol physical and optical properties along the BRV. The short wave aerosol radiative forcing computed using SBDART model also displayed regional variability. The summaries of major observations are mentioned in Table 1.

The following conclusions are drawn based on the observations and analysis of the data:

- The AOD, BC, PM, scattering coefficient, and absorption coefficient are higher over the western sector of the BRV than over the central and eastern sector. Distinct spatial heterogeneity with a continual decrease in the values of most of the parameters was observed as we travelled from west to east along the BRV. Eastern locations are distinctly less polluted compared to the western and middle Assam locations.

- Surface level aerosols in BRV are dominated by PM2.5 throughout the BRV. The BC has significant contribution in total aerosol loading in all stations.

- The coarse mode aerosols probably are of similar density along the valley. The difference in AOD along the valley is because of variation in fine mode aerosols. The low curvature in $\ln \mathrm{AOD}_{\lambda}$ vs $\ln \lambda$ and high $\mathrm{AOD}$ suggest bimodal distribution. There is a dominance of coarse mode particles over the ES and fine mode particles over the WS locations as observed by analyzing the Angstrom exponent computed using different wavelength pairs.

- The analysis of AOD, BC, and PM suggest significant presence of vertically

Table 1. Summary of physical and optical properties of aerosol along the BRV.

\begin{tabular}{|c|c|c|c|c|c|c|c|c|}
\hline $\begin{array}{l}\text { Name of } \\
\text { Station }\end{array}$ & $\begin{array}{c}\text { AOD } \\
(500 \mathrm{~nm})\end{array}$ & $\operatorname{AE}(\alpha)$ & $\begin{array}{c}\text { PM10 } \\
\left(\mu \mathrm{g} \cdot \mathrm{m}^{-3}\right)\end{array}$ & $\begin{array}{c}\text { PM2.5 } \\
\left(\mu \mathrm{g} \cdot \mathrm{m}^{-3}\right)\end{array}$ & $\mathrm{BC}\left(\mu \mathrm{g} \cdot \mathrm{m}^{-3}\right)$ & $\begin{array}{l}\text { Scattering } \\
\text { coefficient }\end{array}$ & $\begin{array}{c}\text { Abs } \\
\text { coefficient }\end{array}$ & SSA \\
\hline $\mathrm{DBH}$ & $0.69 \pm 0.12$ & $1.07 \pm 0.04$ & $26.8 \pm 3.2$ & $25.1 \pm 2.5$ & $17.12 \pm 3.0$ & 0.00163 & 0.00034 & $0.83 \pm 0.09$ \\
\hline GHG & $0.86 \pm 0.12$ & $0.98 \pm 0.05$ & $24.4 \pm 8.8$ & $21.7 \pm 9.7$ & $17.76 \pm 6.3$ & 0.00136 & 0.00042 & $0.77 \pm 0.1$ \\
\hline $\mathrm{BNG}$ & $0.95 \pm 0.07$ & $1.05 \pm 0.05$ & $39.9 \pm 4.2$ & $37.4 \pm 4.1$ & $13.35 \pm 1.7$ & 0.00183 & 0.00022 & $0.89 \pm 0.05$ \\
\hline NBL & $1.03 \pm 0.10$ & $1.08 \pm 0.07$ & $53.7 \pm 4.75$ & $51.8 \pm 3.1$ & $22.5 \pm 4.05$ & 0.00081 & 0.00043 & $0.65 \pm 0.07$ \\
\hline GHY & $0.61 \pm 0.16$ & $1.14 \pm 0.03$ & $37.8 \pm 12.6$ & $35.5 \pm 12.7$ & $17.09 \pm 5.4$ & 0.00081 & 0.00033 & $0.71 \pm 0.06$ \\
\hline NGN & NA & NA & $29.8 \pm 3.7$ & $26.6 \pm 3.1$ & $15.38 \pm 4.1$ & 0.00063 & 0.00033 & $0.66 \pm 0.06$ \\
\hline $\mathrm{TZU}$ & $0.61 \pm 0.11$ & $1.12 \pm 0.07$ & $28.1 \pm 2.1$ & $26.2 \pm 2.1$ & $6.82 \pm 0.89$ & 0.00022 & 0.00014 & $0.62 \pm 0.06$ \\
\hline $\mathrm{BKH}$ & $0.49 \pm 0.09$ & $1.12 \pm 0.08$ & $48.3 \pm 2.9$ & $45.9 \pm 2.7$ & $8.57 \pm 0.82$ & 0.00021 & 0.00018 & $0.55 \pm 0.07$ \\
\hline JRH & $0.45 \pm 0.10$ & $1.07 \pm 0.05$ & $44.6 \pm 10.3$ & $41.8 \pm 10.1$ & $10.2 \pm 1.31$ & 0.00029 & 0.00021 & $0.58 \pm 0.05$ \\
\hline SVG & $0.41 \pm 0.12$ & $1.01 \pm 0.03$ & $42.1 \pm 5.3$ & $39.9 \pm 5.1$ & $9.91 \pm 0.09$ & 0.00030 & 0.00020 & $0.60 \pm 0.09$ \\
\hline DBR & $0.57 \pm 0.18$ & $1.08 \pm 0.04$ & $24.9 \pm 11.2$ & $21.9 \pm 11.2$ & $9.08 \pm 1.22$ & 0.00027 & 0.00014 & $0.66 \pm 0.09$ \\
\hline TSK & $0.77 \pm 0.11$ & $1.15 \pm 0.06$ & $22.6 \pm 1.3$ & $19.6 \pm 1.6$ & $10.03 \pm 1.9$ & 0.00028 & 0.00022 & $0.56 \pm 0.11$ \\
\hline DMD & $0.58 \pm 0.09$ & $1.21 \pm 0.04$ & $21.1 \pm 1.4$ & $18.9 \pm 1.4$ & $12.34 \pm 3.6$ & 0.00039 & 0.00025 & $0.60 \pm 0.08$ \\
\hline
\end{tabular}


distributed aerosol over the extreme western locations, which could have large contribution from transported aerosol from IGP.

- The locations in the western part of the valley are high both in absorption coefficient and scattering coefficient. The difference being more for the scattering coefficient manifests into higher single scattering albedo over the western locations. The sources of absorbing and scattering aerosols are probably the same along the valley.

- Northwesterly surface wind direction travelling along the IGP causes higher aerosol over the entire valley and most significantly over the western sector of the valley.

- The radiative forcing shows the highest surface level forcing over the western locations and the same was continually decreasing as we move from west to east along the valley. Higher $\mathrm{BC}$ aided positive forcing at atmospheric level was observed throughout the valley.

\section{Acknowledgements}

The campaign was carried out with partial support under ISRO-GBP ARFI project. The authors are thankful to Space Physics Laboratory, Trivandrum for their support in procuring instruments under the project and to Prof $\mathrm{P} K$ Bhuian, Centre for Atmospheric Sciences, Dibrugarh University for sharing their instruments during the campaign. The authors are also thankful to NCEP/NCAR for providing the synoptic wind plots.

\section{References}

[1] Andreae, M.O., Jones, C.D. and Cox, P.M. (2005) Strong Present-Day Aerosol Cooling Implies a Hot Future. Nature, 435, 1187-1190.

https://doi.org/10.1038/nature03671

[2] Charlson, R.J., Schwartz S.E., Hales J.M., Cess Jr., R.D., Coakley, J.A., Hansen, J.E. and Hofmann, D.J. (1992) Climate Forcing by Anthropogenic Aerosols. Science, 255, 423-430. https://doi.org/10.1126/science.255.5043.423

[3] Hansen, J., Sato, M. and Ruedy, R. (1997) Radiative Forcing and Climate Response. Journal of Geophysical Research: Atmospheres, 102, 6831-6864.

https://doi.org/10.1029/96JD03436

[4] Lohmann, H. and Feichter, J. (2005) Global Indirect Effects: A Review. Atmospheric Chemistry and Physics, 5, 715-737.

[5] Haywood, J. and Boucher, O. (2000) Estimates of the Direct and Indirect Radiative Forcing Due to Tropospheric Aerosols: A Review. Reviews of Geophysics, 38, 513-543. https://doi.org/10.1029/1999RG000078

[6] Forster, P., Ramaswamy, V., Artaxo, P., Berntsen, T., Betts, R., Fahey, D.W., Haywood, J., Lean, J., Lowe, D.C., Myhre, G., Nganga, J., Prinn, R., Raga, G., Schulz, M. and Van Dorland, R. (2007) Changes in Atmospheric Constituents and in Radiative Forcing. Contribution of Working Group I to the Fourth Assessment Report of the Intergovernmental Panel on Climate Change in Climate Change 2007: The Physical Science Basis, Cambridge University Press, Cambridge, UK, New York, 131-217.

[7] Pilinis, C., Pandis, S.N. and Seinfeld, J.H. (1995) Sensitivity of Direct Climate Forc- 
ing by Atmospheric Aerosols to Aerosol Size and Composition. Journal of Geophysical Research: Atmospheres, 100, 739-754. https://doi.org/10.1029/95JD02119

[8] Stocker, T.F., Qin, D., Plattner, G.K., Tignor, M., Allen, S.K., Boschung, J., Nauels, A., Xia, Y., Bex, V. and Midgley, P.M. (2014) Climate Change 2013: The Physical Science Basis. Contribution of Working Group I to the Fifth Assessment Report of the Intergovernmental Panel on Climate Change, Cambridge University Press, Cambridge, UK, New York, 1535 p.

[9] Kaufman, Y.J., Tanre, D., Dubovik, O., Karnieli, A. and Remer, L.A. (2001) Absorption of Sunlight by Dust as Inferred from Satellite and Ground-Based Remote Sensing. Geophysical Research Letters, 28, 1479-1482.

https://doi.org/10.1029/2000GL012647

[10] Chakrabarty, R.K., Garro, M.A., Wilcox, E.M. and Moosmuller, H. (2012) Strong Radiative Heating Due to Wintertime Black Carbon Aerosols in the Brahmaputra River Valley. Geophysical Research Letters, 39, L09804. https://doi.org/10.1029/2012GL051148

[11] Gustafsson, O., et al. (2009) Brown Clouds over South Asia: Biomass or Fossil Fuel Combustion? Science, 323, 495-498. https://doi.org/10.1126/science.1164857

[12] Menon, S., Hansen, J., Nazarenko, N. and Luo, Y.F. (2002) Climate Effects of Black Carbon Aerosols in China and India. Science, 297, 2250-2253. https://doi.org/10.1126/science.1075159

[13] Rajput, P., Sarin, M. and Kundu, S.S. (2013) Atmospheric Particulate Matter $\left(\mathrm{PM}_{2.5}\right)$, EC, OC, WSOC and PAHs from NE-Himalaya: Abundances and Chemical Characteristics. Atmospheric Pollution Research, 4, 214-221.

https://doi.org/10.5094/APR.2013.022

[14] Moorthy, K.K., Satheesh, S.K., Babu, S.S. and Dutt, C.B.S. (2008) Integrated Campaign for Aerosols, Gases and Radiation Budget (ICARB): An Overview. Journal of Earth System Science, 117, 243-262. https://doi.org/10.1007/s12040-008-0029-7

[15] Gogoi, M.M., Moorthy, K.K., Babu, S.S. and Bhuyan, P.K. (2009) Climatology of Columnar Aerosol Properties and the Influence of Synoptic Conditions: First-Time Results from the Northeastern Region of India. Journal of Geophysical Research: Atmospheres, 114, D08202. https://doi.org/10.1029/2008JD010765

[16] Gogoi, M.M., Pathak, B., Moorthy, K.K., Bhuyan, P.K., Babu, S.S., Bhuyan, K. and Kalita, G. (2011) Multi-Year Investigations of Near Surface and Columnar Aerosols over Dibrugarh, North-Eastern Location of India: Heterogeneity in Source Impacts. Atmospheric Environment, 45, 1714-1724. https://doi.org/10.1016/j.atmosenv.2010.12.056

[17] Pathak, B., Kalita, G., Bhuyan, K., Bhuyan, P.K. and Moorthy, K.K. (2010) Aerosol Temporal Characteristics and Its Impact on Shortwave Radiative Forcing at a Location in the North East of India. Journal of Geophysical Research: Atmospheres, 115, D19204. https://doi.org/10.1029/2009JD013462

[18] Choudhury, B., Saikia, M., Devi, M. and Barbara, A.K. (2013) A Comparative Assessment of Aerosol Optical Properties over Guwahati through Lidar and Satellite Observation. International Journal of Engineering Sciences \& Management, 3, 121-138.

[19] Devi, M., Barbara, A.K., Saikia, M., Choudhury, B. and Sarmah, H. (2012) Micro Pulse Lidar: A Tool for Analyzing Interactive Relation between Aerosol and Cloud Formation. International Journal of Engineering Sciences \& Management, 2, 245-256.

[20] Ramanathan, V., et al. (2001) Indian Ocean Experiment: An Integrated Analysis of 
the Climate Forcing and Effects of the Great Indo-Asian Haze. Journal of Geophysical Research: Atmospheres, 106, 371-398. https://doi.org/10.1029/2001JD900133

[21] Moorthy, K.K., Babu, S.S. and Satheesh, S.K. (2005) Aerosol Characteristics and Radiative Impacts over the Arabian Sea during Inter-Monsoon Season: Results from the ARMEX Field Campaign. Journal of the Atmospheric Sciences, 62, 192-206. https://doi.org/10.1175/JAS-3378.1

[22] Bergstrom, R.W., Schmidt, K.S., Coddington, O., Pilewskie, P., Guan, H., Livingston, J.M., Redemann, J. and Russell, P.B. (2010) Aerosol Spectral Absorption in the Mexico City Area: Results from Airborne Measurements during MILAGRO/INTEX B. Atmospheric Chemistry and Physics, 10, 6333-6343.

[23] Jeong, M.J., Tsay, S.C., Ji, Q., Hsu, N.C., Hansell, R.A. and Lee, J. (2008) Ground-Based Measurements of Airborne Saharan Dust in Marine Environment during the NAMMA Field Experiment. Geophysical Research Letters, 35, L20805. https://doi.org/10.1029/2008GL035587

[24] Moorthy, K.K. (2010) ARFI and ICARB: Overview. Proceedings of the Project Review Meeting, 9-10 June 2010.

[25] Christopher, S.A., Johnson, B., Jones, T.A. and Haywood, J. (2009) Vertical and Spatial Distribution of Dust from Aircraft and Satellite Measurements during the GERBILS Field Campaign. Geophysical Research Letters, 36, L06806.

https://doi.org/10.1029/2008GL037033

[26] Jacob, D.J., Crawford, J.H., Maring, H., Clarke, A.D., Dibb, J.E., Emmons, L.K., Ferrare, R.A., Hostetler, C.A., Russell, P.B., Singh, H.B., Thompson, A.M., Shaw, G.E., McCauley, E., Pederson, J.R. and Fisher, J.A. (2010) The Arctic Research of the Composition of the Troposphere from Aircraft and Satellites (ARCTAS) Mission: Design, Execution, and First Results. Atmospheric Chemistry and Physics, 10, 5191-5212.

[27] Martin, S.T., Andreae, M.O., Artaxo, P., Baumgardner, D., Chen, Q., Goldstein, A.H., Guenther, A., Heald, C.L., Mayol-Bracero, O.L., McMurry, P.H., Pauliquevis, T., Poschl, U., Prather, K.A., Roberts, G.C., Saleska, S.R., Silva-Dias, M.A., Spracklen, D.V., Swietlicki, E. and Trebs, I. (2010) Sources and Properties of Amazonian Aerosol Particles. Reviews of Geophysics, 48, RG2002. https://doi.org/10.1029/2008RG000280

[28] Kulmala, M., Asmi, A., Lappalainen, H.K., et al. (2011) General Overview: European Integrated Project on Aerosol Cloud Climate and Air Quality Interactions (EUCAARI)-Integrating Aerosol Research from Nano to Global Scales. Atmospheric Chemistry and Physics, 11, 13061-13143.

[29] Nakajima, T., Yoon, S.C., Ramanathan, V., Shi, G.Y., et al. (2007) Overview of the Atmospheric Brown Cloud East Asian Regional Experiment 2005 and a Study of the Aerosol Direct Radiative Forcing in East Asia. Journal of Geophysical Research: Atmospheres, 112, D24S91. https://doi.org/10.1029/2007JD009009

[30] Rahul, P.R.C., Bhawar, R.L., Ayantika, D.C., Panicker, A.S., Safai, P.D., Tharaprabhakaran V., Padmakumari, B. and Raju, M.P. (2014) Double Blanket Effect Caused by Two Layers of Black Carbon Aerosols Escalates Warming in the Brahmaputra River Valley. Scientific Reports, 4, Article No. 3670. https://doi.org/10.1038/srep03670

[31] Jayaraman, A., Gadhavi, H., Ganguly, D., Misra, A., Ramachandran, S. and Rajesh, T. (2006) Spatial Variation in Aerosol Characteristics over Central India Observed during the February 2004 Road Campaign Experiment. Atmospheric Environment, 40, 6504-6515. https://doi.org/10.1016/j.atmosenv.2006.01.034 
[32] Pathak, B., Bhuyan, P.K., Biswas, J. and Takemura, T. (2013) Long Term Climatology of Particulate Matter and Associated Microphysical and Optical Properties over Dibrugarh, North East India and Inter-Comparison with SPRINTARS Simulations. Atmospheric Environment, 69, 334-344.

[33] Hansen, A.D.A., Rosen, H. and Novakov, T. (1984) The Aethalometer-An Instrument for the Real-Time Measurement of Optical Absorption by Aerosol Particles. Science of the Total Environment, 36, 191-196. https://doi.org/10.1016/0048-9697(84)90265-1

[34] Nair, V.S., Moorthy, K.K., Alappattu, D.P., Kunhikrishnan, P.K., George, S., Nair, P.R. and Babu, S.S. (2007) Wintertime Aerosol Characteristics over the Indo-Gangetic Plain (IGP): Impacts of Local Boundary Layer Processes and Long-Range Transport. Journal of Geophysical Research: Atmospheres, 112, D13205. https://doi.org/10.1029/2006JD008099

[35] Weingartner, E., Saathoff, H., Schnaiter, M., Strit, N., Bitnar, B. and Baltensperger, U. (2003) Absorption of Light by Soot Particles: Determination of the Absorption Coefficient by Means of Aethalometers. Journal of Aerosol Science, 34, 1445-1463. https://doi.org/10.1016/S0021-8502(03)00359-8

[36] Morys, M., Mims III, F.M., Hagerup, S., Anderson, S.E., Baker, A., Kia, J. and Walkup, T. (2001) Design, Calibration, and Performance of MICROTOPS II Hand-Held Ozone Monitor and Sun Photometer. Journal of Geophysical Research: Atmos pheres, 106, 14573-14582. https://doi.org/10.1029/2001JD900103

[37] Ricchiazzi, P., Yang, S., Gautier, C. and Sowle, D. (1998) SBDART: A Research and Teaching Software Tool for Plane-Parallel Radiative Transfer in the Earth's Atmosphere. Bulletin of the American Meteorological Society, 79, 2101-2114. https://doi.org/10.1175/1520-0477(1998)079<2101:SARATS >2.0.CO;2

[38] Dubovik, O., Holben, B.N., Eck, T.F., Smirnov, A., Kaufman, Y.J., King, M.D., Tanre, D. and Slutsker, I. (2002) Variability of Absorption and Optical Properties of Key Aerosol Types Observed in Worldwide Locations. Journal of the Atmospheric Sciences, 59, 590-608. https://doi.org/10.1175/1520-0469(2002)059<0590:VOAAOP >2.0.CO;2

[39] Eck, T.F., Holben, B.N., Reid, J.S., Dubovic, O., Smirnov, A., O’Neill, N.T., Slutsker, I. and Kinne, S. (1999) Wavelength Dependence of the Optical Depth of Biomass Burning, Urban, and Desert Dust Aerosols. Journal of Geophysical Research: At mospheres, 104, 31333-31349. https://doi.org/10.1029/1999JD900923

[40] Angstrom, A. (1929) On the Atmospheric Transmission of Sun Radiation and on Dust in the Air. Geografiska Annaler, 11, 156-166. https://doi.org/10.2307/519399

[41] Pathak, B., Bhuyan, P.K., Gogoi, M.M. and Bhuyan, K. (2012) Seasonal Heterogeneity in Aerosol Types over Dibrugarh-North-Eastern India. Atmospheric Environment, 47, 307-315. https://doi.org/10.1016/j.atmosenv.2011.10.061

[42] Ganguly, D., Jayaraman, A. and Gadhavi, H. (2006) Physical and Optical Properties of Aerosols over an Urban Location in Western India: Seasonal Variabilities. Journal of Geophysical Research: Atmospheres, 111, D242007A06. https://doi.org/10.1029/2006JD007392

[43] Cachorro, V.E., Vergaz, R., Martin, M.J., De Frutos, A.M., Vilaplana, J.M. and De la Morena, B. (2002) Measurements and Estimation of the Columnar Optical Depth of Tropospheric Aerosols in the UV Spectral Region. Annales Geophysicae, 20, 565-574.

[44] Reid, J.S., Eck, T.F., Christopher, S.A., Hobbs, P.V. and Holben, B.N. (1999) Use of the Ångstrom Exponent to Estimate the Variability of Optical and Physical Proper- 
ties of Aging Smoke Particles in Brazil. Journal of Geophysical Research: Atmospheres, 104, 27473-27489. https://doi.org/10.1029/1999JD900833

[45] Kaskaoutis, D.G. and Kambezidis, H.D. (2006) Checking the Validity of the Angstrom's Formula with Spectral Data of Direct-Beam Irradiance Obtained in Athens, Greece. Atmospheric Research, 79, 67-87. https://doi.org/10.1016/j.atmosres.2005.05.001

[46] Eck, T.F., Holben, B.N., Dubovic, O., Smirnov, A., Slutsker, I., Lobert, J.M. and Ramanathan, V. (2001) Column-Integrated Aerosol Optical Properties over the Maldives during the Northeast Monsoon for 1998-2000. Journal of Geophysical Research: Atmospheres, 106, 28555-28566. https://doi.org/10.1029/2001JD000786

[47] Eck, T.F., Holben, B.N., Dubovic, O., Smirnov, A., Goloub, P., Chen, H.B., Chatenet, B., Gomes, L., Zhang, X.Y., Tsay, S.C., Ji, Q., Giles, D. and Slutsker, I. (2005) Columnar Aerosol Optical Properties at AERONET Sites in Central Eastern Asia and Aerosol Transport to the Tropical Mid-Pacific. Journal of Geophysical Research: Atmospheres, 110, D06202. https://doi.org/10.1029/2004JD005274

[48] O’Neill, N.T., Eck, T.F., Holben, B.N., Smirnov, A., Dubovik, O. and Royer, A. (2001) Bimodal Size Distribution Influences on the Variation of the Ångström Derivatives in Spectral and Optical Depth Space. Journal of Geophysical Research: Atmospheres, 106, 9787-9806. https://doi.org/10.1029/2000JD900245

[49] Pedrós, R., Martinez-Lozano, J.A., Utrillas, M.P., Gomez-Amo, J.L. and Tena, F. (2003) Column-Integrated Aerosol, Optical Properties from Ground-Based Spectroradiometer Measurements at Barrax (Spain) during the Digital Airborne Imaging Spectrometer Experiment (DAISEX) Campaigns. Journal of Geophysical Research: Atmospheres, 108, 4571-4587. https://doi.org/10.1029/2002JD003331

[50] Kaskaoutis, D.G., Kambezidis, H.D., Hatzianastassiou, N., Kosmopoulos, P.G. and Badarinath, K.V.S. (2007) Aerosol Climatology: Dependence of the Angstrom Exponent on Wavelength over Four AERONET Sites. Atmospheric Chemistry and Physics, 7, 7347-7397. https://doi.org/10.5194/acpd-7-7347-2007

[51] Schuster, G.L., Dubovik, O. and Holben, B.N. (2006) Angstrom Exponent and Bimodal Aerosol Size Distributions. Journal of Geophysical Research: Atmospheres, 111, D07207. https://doi.org/10.1029/2005JD006328

[52] Pathak, B., Borgohain, A., Bhuyan, P.K., Kundu, S.S., Sudhakar, S., Gogoi, M.M. and Takemura, T. (2014) Spatial Heterogeneity in Near Surface Aerosol Characteristics across the Brahmaputra Valley. Journal of Earth System Science, 123, 651-663. https://doi.org/10.1007/s12040-014-0431-2

[53] Bond, T.C., Doherty, S.J., Fahey, D.W., et al. (2013) Bounding the Role of Black Carbon in the Climate System: A Scientific Assessment. Journal of Geophysical Research: Atmospheres, 118, 5380-5552. https://doi.org/10.1002/jgrd.50171

[54] Kirchstetter, T.W., Novakov, T. and Hobbs, P.V. (2004) Evidence That the Spectral Dependence of Light Absorption by Aerosols Is Affected by Organic Carbon. Journal of Geophysical Research: Atmospheres, 109, D21208. https://doi.org/10.1029/2004JD004999

[55] Ganguly, D., Jayaraman, A., Gadhavi, H. and Rajesh, T.A. (2005) Features in Wavelength Dependence of Aerosol Absorption Observed over Central India. Geophysical Research Letters, 32, L13821. https://doi.org/10.1029/2005GL023023

[56] Krishnan, P. and Kunhikrishnan, P.K. (2004) Temporal Variations of Ventilation Coefficient at a Tropical Indian Station Using UHF Wind Profiler. Current Science, 86, 447-451.

[57] Takemura, T., Nakajima, T., Dubovik, O., Holben, B.N. and Kinne, S. (2002) Sin- 
gle-Scattering Albedo and Radiative Forcing of Various Aerosol Species with a Global Three-Dimensional Model. Journal of Climate, 15, 333-352. https://doi.org/10.1175/1520-0442(2002)015<0333:SSAARF>2.0.CO;2

[58] Ackerman, A.S., Toon, O.B., Stevens, D.E., Heymsfield, A.J., Ramanathan, V. and Welton, E.J. (2000) Reduction of Tropical Cloudiness by Soot. Science, 288, 1042-1047. https://doi.org/10.1126/science.288.5468.1042

[59] Heintzenberg, J. and Charlson, R.J. (1996) Design and Applications of the Integrating Nephelometer: A Review. Journal of Atmospheric and Oceanic Technology, 13, 987-1000. https://doi.org/10.1175/1520-0426(1996)013<0987:DAAOTI>2.0.CO;2

[60] Tripathi, S.N., Dey, S., Tare, V. and Satheesh, S.K. (2005) Aerosol Black Carbon Radiative Forcing at an Industrial City in Northern India. Geophysical Research Letters, 32, L08802. https://doi.org/10.1029/2005GL022515

[61] Hess, M., Keopke, P. and Schult, I. (1998) Optical Properties of Aerosols and Clouds: The Software Package OPAC. Bulletin of the American Meteorological Society, 79, 831-844. https://doi.org/10.1175/1520-0477(1998)079<0831:OPOAAC >2.0.CO;2

[62] Gogoi, M.M., Babu, S.S., Moorthy, K.K., Bhuyan, P.K., Pathak, B., Subba, T., Chutia, L., Kundu, S.S., Bharali, C., Borgohain, A., Guha, A., De, B.K., Singh, B. and Chin, M. (2017) Radiative Effects of Absorbing Aerosols over Northeastern India: Observations and Model Simulations. Journal of Geophysical Research: Atmospheres, 122, 1132-1157. https://doi.org/10.1002/2016JD025592

[63] Pathak, B., Subba, T., Dahutia, P., Bhuyan, P.K., Moorthy, K.K., Gogoi, M.M., Babu, S.S., Chutia, L., Ajay, P., Biswas, J., Bharali, C., Borgohain, A., Dhar, A., Guha, A., De, B.K., Banik, T., Chakraborty, M., Kundu, S.S., Singh, S.B. and Sudhakar, S. (2015) Aerosol Characteristics in North-East India Using ARFINET Spectral Optical Depth Measurements. Atmospheric Environment, 125, 461-473. https://doi.org/10.1016/j.atmosenv.2015.07.038

[64] Kim, D. and Ramanathan, V. (2008) Solar Radiation Budget and Radiative Forcing Due to Aerosols and Clouds. Journal of Geophysical Research: Atmospheres, 113, D02203. https://doi.org/10.1029/2007JD008434 